\title{
Management of malignant pleural effusions
}

\author{
V.B. Antony*, R. Loddenkemper", P. Astoul", C. Boutin", P. Goldstraw ${ }^{+}$, J. Hott*, \\ F. Rodriguez Panadero§, S.A. Sahn ${ }^{f}$
}

\section{CONTENTS}

\begin{abstract}
Aetiology and pathogenesis . . . . . . . . . 402
Diagnostic approaches . . . . . . . . . . . . . . . . . . .

Clinical manifestations . . . . . . . . . . . . 403

Imaging techniques. . . . . . . . . . . . . . . . . 403

Diagnostic thoracentesis . . . . . . . . . . . . . . 404

Closed pleural biopsy . . . . . . . . . . . . . . . 405

Medical thoracoscopy. . . . . . . . . . . . . . 405

Bronchoscopy . . . . . . . . . . . . . . . 406

Surgical biopsy. . . . . . . . . . . . . . . . . . . . . . . . . . . . . . . . . . .

Treatment ...................406

Indications and contraindications . . . . . . 406

Therapeutic thoracentesis . . . . . . . . . . . . 407

Chemical pleurodesis . . . . . . . . . . . . . 407

Talc pleurodesis . . . . . . . . . . . . . . . 408
\end{abstract}

Malignant pleural effusions are a common clinical problem in patients with neoplastic disease. In one post mortem series, malignant effusions were found in $15 \%$ of patients who died with malignancies [1]. Although there have been no epidemiological studies, the annual incidence of malignant pleural effusions in the United States is estimated to be $>150,000$ cases (table 1) [2-17]. Malignant pleural effusion is also one of the leading causes of exudative effusion; studies have demonstrated that $42-77 \%$ of exudative effusions are secondary to malignancy $[18,19]$.

\section{Aetiology and pathogenesis}

Nearly all neoplasms have been reported to involve the pleura. In most studies, however, lung carcinoma has been the most common neoplasm, accounting for approximately one-third of all malignant effusions. Breast carcinoma is the second most common. Lymphomas, including both Hodgkin's disease and non-Hodgkin's lymphoma, are also an important cause of malignant pleural effusions. Tumours less commonly associated with malignant pleural effusions include ovarian and gastrointestinal carcinomas. In
Treatment of pleurodesis failure. . . . . . . . . . . 410

Other treatments . . . . . . . . . . . . . . . . 410

Malignant pleural effusions in specific diseases . . . 411

Lung carcinoma . . . . . . . . . . . . . . . 411

Mesothelioma . . . . . . . . . . . . . 411

Breast carcinoma . . . . . . . . . . . . . . . . . 412

Lymphoma, leukaemia, and multiple myeloma . . 412

Factors affecting prognosis . . . . . . . . . . . 413

Future directions for research . . . . . . . . . . . 413

Definitions of success or failure of pleurodesis . . 413

Prospects for clinical studies . . . . . . . . . . . . . . . . . . . . . . . . .

Gene therapy ............ . . . . . 413

Cellular basis of malignant effusions and

pleurodesis. . . . . . . . . . . . . . . . . . . 4414

$5-10 \%$ of malignant effusions, no primary tumour is identified $[12,13]$. The incidence of mesothelioma varies according to the geographical location.

Post mortem studies suggest that most pleural metastases arise from tumour emboli to the visceral pleural surface, with secondary seeding to the parietal pleura $[1,20]$. Other possible mechanisms include direct tumour invasion (in lung cancers, chest wall neoplasms, and breast carcinoma), haematogenous spread to parietal pleura, and lymphatic involvement. A malignant tumour can cause a pleural effusion, both directly and indirectly. Interference with the integrity of the lymphatic system anywhere between the parietal pleura and mediastinal lymph nodes can result in pleural fluid formation [12, 20]. Direct tumour involvement with the pleura may also contribute to the formation of pleural effusions. Local inflammatory changes in response to tumour invasion may cause increased capillary permeability, with resultant effusions [21].

The term "paramalignant effusions" is reserved for those effusions that are not the direct result of neoplastic involvement of the pleura but are still related to the primary tumour (table 2) [22]. Important examples include: postobstructive pneumonia,

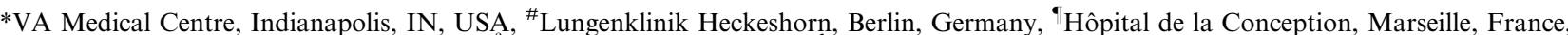
${ }^{+}$Royal Brompton Hospital, London, UK, ${ }^{\S}$ El Mirador, Seville, Spain, ${ }^{f}$ Medical University of South Carolina, Charleston, SC, USA.
} 
Table 1. - Incidence of malignant pleural effusions (MPEs)

\begin{tabular}{|c|c|c|c|c|c|}
\hline & $\begin{array}{c}\text { Patients } \\
\text { with MPE (all } \\
\text { stages)*\% }\end{array}$ & $\begin{array}{c}\text { Patients with } \\
\text { disseminated } \\
\text { disease or at } \\
\text { autopsy with MPE } \%\end{array}$ & $\begin{array}{l}\text { Origin of primary } \\
\text { tumour from } \\
\text { cytology } \\
\text { reviews } \%\end{array}$ & $\begin{array}{c}\text { Annual cancer } \\
\text { deaths in the } \\
\text { USA }^{+}\end{array}$ & $\begin{array}{c}\text { Estimated cases } \cdot \mathrm{yr}^{-1} \\
\text { of MPE } \\
\text { in the USA }\end{array}$ \\
\hline Lung cancer & $8-15$ & $20-46$ & $25-52$ & 160,000 & $32,000-73,600^{\S}$ \\
\hline Breast cancer & $2-12$ & $36-65$ & $3-27$ & 44,000 & $15,840-28,600^{\S}$ \\
\hline Lymphoma & 7 & $29-30$ & $12-22$ & 25,000 & $7,250-7,500^{\S}$ \\
\hline Other malignancies & & & $29-46$ & 330,000 & $23,600-47,000^{f}$ \\
\hline Total & & & & & $78,700-156,700$ \\
\hline
\end{tabular}

*: [2-7]; ${ }^{\#}:$ [8-11]; ${ }^{\text {ๆ }: ~[12-16] ; ~}{ }^{+}:$[17]; ${ }^{\S}$ : percentage of patients with MPE (disseminated/autopsy) $\times$ cancer deaths; ${ }^{f}:$ assumes $30 \%$ of MPE are from "other malignancies".

with a subsequent parapneumonic effusion; obstruction of the thoracic duct, with the development of a chylothorax; pulmonary embolism; and transudative effusions secondary to postobstruction atelectasis and/or low plasma oncotic pressures secondary to cachexia. Treatment of the primary tumour can also result in pleural effusions. Important causes in this category include radiation therapy and such drugs as methotrexate, procarbazine, cyclophosphamide, and bleomycin. Finally, concurrent nonmalignant disease, such as congestive heart failure, may account for an effusion seen in a patient with cancer.

\section{Diagnostic approaches}

\section{Clinical manifestations}

Dyspnoea is the most common presenting symptom in patients with malignant effusions, occurring in more than half the cases [12]. Because of the advanced stage of their primary disease, many patients also present with generalized symptoms such as weight loss, anorexia, and malaise. The pathogenesis of dyspnoea caused by a large pleural effusion has not been clearly elucidated, but several factors may be involved, including a decrease in the compliance of the chest wall, contralateral shifting of the mediastinum, a decrease in the ipsilateral lung volume, and reflex stimulation from the lungs and chest wall [23].

Additional symptoms may be related to specific conditions. Chest pain, commonly seen in mesothelioma, is typically localized to the side of the effusion, and is described as dull and aching rather than pleuritic [24]. A history of haemoptysis in the presence of a pleural effusion is highly suggestive of bronchogenic carcinoma. A prior history of malignancy is obviously important, as are any relevant occupational exposures, especially to asbestos or other carcinogens. Most patients presenting with malignant effusions have large enough effusions to cause the chest examination to be abnormal. Other clinically relevant findings may include cachexia and adenopathy [12].

\section{Imaging techniques}

Most patients presenting with malignant pleural effusions have some degree of dyspnoea on exertion and their chest radiographs show moderate-to-large

Table 2. - Causes of paramalignant pleural effusions

\begin{tabular}{|c|c|}
\hline Cause & Comment \\
\hline \multicolumn{2}{|l|}{ Local effects of tumour } \\
\hline Lymphatic obstruction & Predominant mechanism for pleural fluid accumulation \\
\hline Bronchial obstruction with pneumonia & Parapneumonic effusion; does not exclude operability in lung cancer \\
\hline Bronchial obstruction with atelectasis & Transudate; does not exclude operability in lung cancer \\
\hline Trapped lung & Transudate; due to extensive tumour involvement of visceral pleura \\
\hline Chylothorax & Disruption of thoracic duct; lymphoma most common cause \\
\hline Superior vena cava syndrome & Transudate; due to increased systemic venous pressure \\
\hline \multicolumn{2}{|l|}{ Systemic effects of tumour } \\
\hline Pulmonary embolism & Hypercoagulable state \\
\hline Hypoalbuminemia & Serum albumin $<1.5 \mathrm{~g} \cdot \mathrm{dL}^{-1}$; associated with anasarca \\
\hline \multicolumn{2}{|l|}{ Complications of therapy } \\
\hline \multicolumn{2}{|l|}{ Radiation therapy } \\
\hline Early & Pleuritis 6 weeks to 6 months after radiation completed \\
\hline \multirow[t]{3}{*}{ Late } & Fibrosis of mediastinum \\
\hline & Constrictive perficarditis \\
\hline & Vena caval obstruction \\
\hline \multicolumn{2}{|l|}{ Chemotherapy } \\
\hline Methotrexate & Pleuritis or effusion; with or without blood eosinophilia \\
\hline Procarbazine & Blood eosinophilia; fever and chills \\
\hline Cyclophosphamide & Pleuropericarditis \\
\hline Mitomycin/bleomycin & In association with interstitial disease \\
\hline
\end{tabular}


pleural effusions ranging from $\sim 500-2,000 \mathrm{~mL}$ in volume [12]. While only $10 \%$ of patients have massive pleural effusions on presentation, malignancy is the most common cause of massive pleural effusion [25]. Massive pleural effusions are defined as those effusions occupying the entire hemithorax. About $15 \%$ of patients, however, will have pleural effusions $<500 \mathrm{~mL}$ in volume and will be relatively asymptomatic. An absence of contralateral mediastinal shift in these large effusions implies fixation of the mediastinum, mainstem bronchus occlusion by tumour (usually squamous cell lung cancer), or extensive pleural involvement (as seen with malignant mesothelioma).

Computed tomography (CT) of patients with malignancies may identify previously unrecognized small effusions. They may also aid in the evaluation of patients with malignant effusions for mediastinal lymph node involvement and underlying parenchymal disease, as well as in demonstrating pleural, pulmonary, or distant metastases [26]; identification of pleural plaques suggests asbestos exposure. Ultrasonography may aid in identifying pleural lesions in patients with malignant effusions and can be helpful in directing thoracentesis in patients with small effusions and avoiding thoracentesis complications [27]. The role of magnetic resonance imaging (MRI) in malignant effusions appears limited, but MRI may be helpful in evaluating the extent of chest wall involvement by tumour [28-30]. There is little information available on the utilization of fluorodeoxyglucose positron emission tomography (PET) in malignant pleural effusions, although it has been reported as helpful in evaluating the extent of disease in malignant mesothelioma [31].

\section{Diagnostic thoracentesis}

Malignancy should be considered and a diagnostic thoracentesis performed in any individual with a unilateral effusion or bilateral effusion and a normal heart size on the chest radiograph. It is reasonable to order the following pleural fluid tests when considering malignancy: nucleated cell count and differential, total protein, lactate dehydrogenase (LDH), glucose, $\mathrm{pH}$, amylase, and cytology. There are no absolute contraindications to performing thoracentesis. Relative contraindications include a minimal effusion $(<1 \mathrm{~cm}$ in thickness from the fluid level to the chest wall on a lateral decubitus view), bleeding diathesis, anticoagulation, and mechanical ventilation. There is no increased bleeding in patients with mild-tomoderate coagulopathy or thrombocytopenia (a prothrombin time or partial thromboplastin time up to twice the midpoint normal range and a platelet count of $\left.>50,000 \cdot \mu \mathrm{L}^{-1}\right)$. However, patients with serum creatinine levels of $>6.0 \mathrm{mg} \cdot \mathrm{dL}^{-1}$ are at a considerable risk of bleeding [32]. Important complications of thoracentesis include pneumothorax, bleeding, infection, and spleen or liver laceration. Almost all malignant pleural effusions are exudates [33, 34]; a few are, however, transudates. Paramalignant effusions are caused by mediastinal node involvement, endobronchial obstruction with atelectasis, or concomitant nonmalignant disease, most notably congestive heart failure $[12,35,36]$. This does not suggest that every individual with a transudative pleural effusion should have pleural fluid cytological examination. However, in the appropriate clinical setting and the absence of congestive heart failure or a pleural fluid LDH level near the exudative range, determination of pleural fluid cytology is suggested.

Although malignancy is a common cause of bloody effusions, at least half are not grossly haemorrhagic [31]. The pleural fluid nucleated cell count typically shows a predominance of either lymphocytes or other mononuclear cells $[37,38]$. The presence of $>25 \%$ lymphocytes is unusual; pleural fluid eosinophilia does not exclude a malignant effusion [37, 39, 40].

Approximately one-third of malignant effusions have a pleural fluid $\mathrm{pH}$ of $<7.30$ at presentation [41, 42]; this low $\mathrm{pH}$ is associated with glucose values of $<60 \mathrm{mg} \cdot \mathrm{dL}^{-1}$ [43]. The cause of these low-glucose, low-pH malignant effusions appears to be an increased tumour mass within the pleural space compared with those with a higher $\mathrm{pH}$ effusion, resulting in decreased glucose transfer into the pleural space and decreased efflux of the acidic by-products of glucose metabolism, carbon dioxide $\left(\mathrm{CO}_{2}\right)$, and lactic acid, due to an abnormal pleural membrane [44, 45]. Malignant effusions with a low $\mathrm{pH}$ and glucose concentration have been shown to have a higher initial diagnostic yield on cytological examination, a worse survival, and a worse response to pleurodesis than those with normal $\mathrm{pH}$ and glucose [41-45]. However, other investigators have not found an association between pleural fluid $\mathrm{pH}$ in malignant effusions and survival or success of pleurodesis [46-50]. A meta-analysis of patient-level data from nine sources encompassing $>400$ patients, found that pleural fluid $\mathrm{pH}$ was an independent predictor of survival. A pleural fluid $\mathrm{pH}$ threshold $\leqslant 7.28$ had the highest accuracy for identifying poor 1-, 2-, and 3 -month survivals. Only $55 \%$ of patients identified by pleural fluid $\mathrm{pH} \leqslant 7.28$, however, die within 3 months. The authors concluded that pleural fluid $\mathrm{pH}$ has insufficient predictive accuracy for selecting patients for pleurodesis on the basis of estimated survival [51]. The same investigators also found that pleural fluid $\mathrm{pH}$ had only modest predictive value for predicting symptomatic failure from pleurodesis [52]. The pleural fluid $\mathrm{pH}$ should be used only in conjunction with the patient's general health, performance status, primary tumour type, and response to therapeutic thoracentesis, in deciding appropriateness for pleurodesis [51, 53].

Elevated pleural fluid amylase levels (salivary isotype) in the absence of oesophageal rupture greatly increases the likelihood that the pleural effusion is malignant, most commonly adenocarcinoma of the lung $[54,55]$. Although once thought to be helpful in the diagnosis of mesothelioma, hyaluron levels have limited diagnostic importance because they can be elevated in other malignant effusions as well as in benign pleural processes [56].

Pleural fluid cytology is the simplest definitive method for obtaining a diagnosis of malignant pleural effusion. The diagnostic yield is dependent on such 
factors as extent of disease and the nature of the primary malignancy. Therefore, studies have shown a large variation in diagnostic yields ranging from $62-90 \%[13,14,16,57,58]$. The diagnostic yield of cytology for mesothelioma is 58\%.

Other procedures, such as immunohistochemical staining with monoclonal antibodies to tumour markers and chromosome analysis, have been proposed to aid further in diagnosis. Because of their relatively low sensitivities and specificities, they cannot be relied on for definitive diagnosis; they may nevertheless be of some benefit in certain circumstances. Identification of deoxyribonucleic acid (DNA) aneuploidy by flow cytometry may add to routine cytology by detecting false negatives in the initial cytological screening, warranting further review by the cytopathologists [59]. Chromosome analysis may be useful in cases of lymphoma and leukaemia [60]. In some cases differentiating between reactive mesothelial cells, mesothelioma, and adenocarcinoma can be problematic. Tumour markers such as carcinoembryonic antigen (CEA), Leu-1, and mucin, may be helpful in establishing the diagnosis, as they are frequently positive in adenocarcinomas $(50-90 \%)$ but rarely seen with mesothelial cells or mesothelioma $(0-10 \%)$ [61-71].

\section{Closed pleural biopsy}

In malignant effusions, closed pleural biopsies are less sensitive than pleural fluid cytology. These blind percutaneous biopsies of the costal (parietal) pleura report a diagnostic yield of $40-75 \%[15,57,58,72,73]$. If abnormalities of the pleura are identified with CT, as in mesothelioma, a CT-guided biopsy is performed [74]. The relatively low yield of blind pleural biopsy is due to several factors, including early stage of disease with minimal pleural involvement, distribution of tumour in areas not sampled during blind biopsy, and operator inexperience [75]. However, studies have shown that $7-12 \%$ of patients with malignant effusions may be diagnosed by pleural biopsy when fluid cytology is negative $[15,58]$.

Contraindications to pleural biopsy include bleeding diathesis, anticoagulation, chest wall infection, and lack of patient cooperation. Important complications include pneumothorax, haemothorax, and vasovagal reactions. Postbiopsy pneumothoraces are frequently due to air entry from the needle during the procedure and do not often require intervention. A rapid clinical deterioration or increased postprocedure effusion should alert the clinician to possible haemothorax [76].

\section{Medical thoracoscopy}

Medical thoracoscopy as compared with surgical thoracoscopy (which is more precisely known as video-assisted thoracic surgery (VATS; see also surgical biopsy) has the advantage that it can be performed under local anaesthesia or conscious sedation, in an endoscopy suite, using nondisposable rigid instruments. Thus, it is considerably less invasive and less expensive than VATS. The technique is similar to chest tube insertion by means of a trocar, the difference being that, in addition, the pleural cavity can be visualized and biopsies can be taken from all areas of the pleural cavity including the chest wall, diaphragm, mediastinum, and lung. Medical thoracoscopy can be performed either under direct visual control through the optical shaft of the thoracoscope, or indirectly by video transmission, which allows demonstration to assistants and others as well as an appropriate documentation. Medical thoracoscopy is primarily a diagnostic procedure. Indicators for its use include the evaluation of exudative effusions of unknown cause, staging of malignant mesothelioma or lung cancer, and treatment of malignant or other recurrent effusions with talc pleurodesis. Another purpose may be biopsy of the diaphragm, lung, mediastinum, or pericardium [77-79].

In cases of undiagnosed exudative effusions with a high clinical suspicion for malignancy, some clinicians may proceed directly to thoracoscopy if the facilities for medical thoracoscopy are available. The procedure should be performed for diagnosis and possible talc poudrage. Diagnostic yields of nonsurgical biopsy methods for malignant pleural effusions were studied in 208 patients, each of whom underwent all studied procedures [79]. Diagnoses included 58 malignant mesotheliomas, 29 bronchogenic carcinomas, and 116 metastatic pleural effusions (28 breast cancers, 30 cancers of various other organs, and 58 of undetermined origin), and five lymphomas. The diagnostic yield was $62 \%$ by pleural fluid cytology, $44 \%$ by closed pleural biopsy, and $95 \%$ by medical thoracoscopy (fig. 1). The sensitivity of medical thoracoscopy was higher than that of cytology and closed pleural biopsy combined (96 versus 74\%, $\mathrm{p}<0.001$ ). The combined methods were diagnostic in $97 \%$ of the malignant pleural effusions. In 6 of the 208 cases $(2.8 \%)$, an underlying neoplasm was suspected at thoracoscopy, but confirmed only by thoracotomy or autopsy. Similar results have been reported by other investigators [80-83].

The reasons for false-negative thoracoscopy include insufficient and nonrepresentative biopsies that depend largely on the experience of the thoracoscopist $[80,84]$ and the presence of adhesions that prevent access to neoplastic tissue $[77,80]$. Adhesions are often a consequence of repeated therapeutic thoracenteses $[77,85]$.

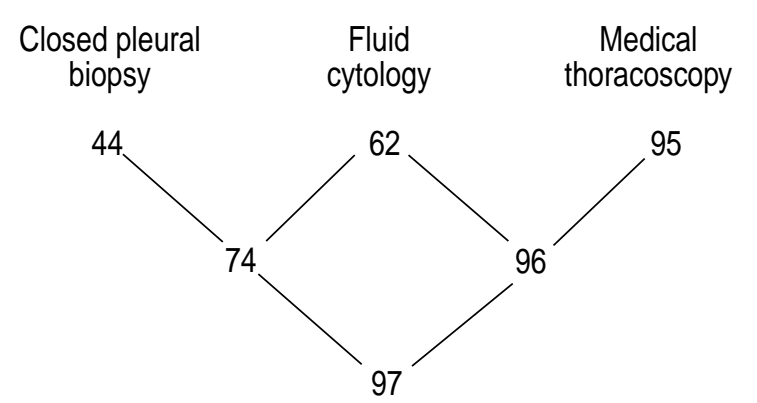

Fig. 1.-Malignant pleural effusions: sensitivity (\%) of different biopsy methods (cytological and histological results combined). Presented is a prospective simultaneous comparison $(n=208)$. 


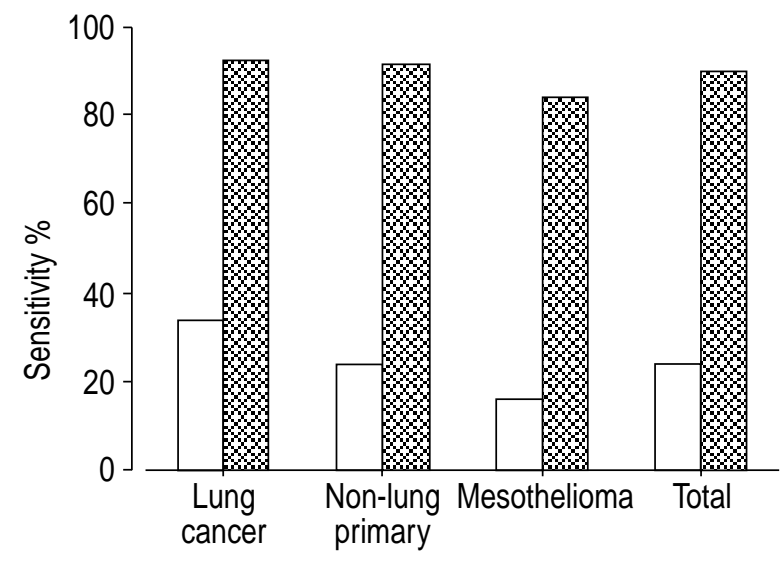

Fig. 2.-Diagnostic sensitivity of cytology ( $\square$ ) and medical thoracoscopy (霍) in malignant pleural effusions. n-numbers are as follows: lung cancer, 67; non-lung primary, 154; mesothelioma, 66; total, 287.

The diagnostic sensitivity of medical thoracoscopy is similar for all types of malignant effusions (fig. 2). The diagnostic sensitivity in 287 cases was $62 \%$ for cytology and $95 \%$ for medical thoracoscopy; the sensitivity of cytology and thoracoscopy did not vary among lung carcinomas (67 versus 96\%), extrathoracic primaries (62 versus 96\%), and diffuse malignant mesotheliomas (58 versus 92\%) [79].

Medical thoracoscopy may be more useful than thoracotomy in staging patients with lung cancer and diffuse malignant mesothelioma. In patients with lung cancer, thoracoscopy can help determine whether the effusion is malignant or paramalignant. As a result, it may be possible to avoid exploratory thoracotomy for tumour staging. WEISSBERG et al. [86] performed medical thoracoscopy in 45 patients with lung cancer and a pleural effusion, and found pleural invasion in 37, mediastinal disease in three, and no metastatic disease in five $(11 \%)$ and therefore, no contraindication to resection [86]. CANTó et al. [87] found no thoracoscopic evidence of pleural involvement in eight of 44 patients; six proceeded to resection with no pleural involvement found. A more recent study by CANTÓ et al. [88] demonstrated that diagnostic sensitivity of malignancy was associated with the size of the effusion.

In diffuse malignant mesothelioma, medical thoracoscopy can provide earlier diagnosis, better histological classification than closed pleural biopsy because of larger and more representative biopsies, and more accurate staging [89-91]. In addition, fibrohyaline or calcified, thick, pearly white pleural plaques may be found, diagnosing benign asbestos pleural effusion (BAPE) and excluding mesothelioma or malignancies [92]. Thoracoscopic lung biopsies, as well as biopsies from lesions on the parietal pleura [93], may demonstrate high concentrations of asbestos fibres, providing further support for a diagnosis of asbestos-induced disease.

A further advantage of medical thoracoscopy in metastatic pleural disease is that biopsies of the visceral and diaphragmatic pleura are possible under direct observation. The thorascopic biopsies can provide easier identification of primary tumour [80], including hormone receptors in breast cancer [94], and improved morphological classification in lymphomas [95].

Medical thoracoscopy is of further value in excluding malignancy and tuberculosis in undiagnosed effusions [79]. After thoracoscopy, $<10 \%$ of effusions remain undiagnosed [80, 83, 96, 97]; whereas with pleural fluid analysis and closed needle biopsy, more than $20 \%$ remained undiagnosed [98-100]. In the few cases in which thoracoscopy is not possible (or diagnosis remains elusive even after thoracoscopy), VATS or exploratory thoracotomy may be indicated [101].

\section{Bronchoscopy}

The diagnostic yield of bronchoscopy is low in patients with undiagnosed pleural effusions and should not be undertaken routinely [102-104]. However, it is indicated when endobronchial lesions are suspected because of haemoptysis, atelectasis, or large effusions without contralateral mediastinal shift. Bronchoscopy should also be performed to exclude endobronchial obstruction before attempting pleurodesis when there is absence of lung expansion after therapeutic thoracentesis.

\section{Surgical biopsy}

VATS procedures usually require general anaesthesia and single-lung ventilation. The surgeon may undertake a more extensive procedure than medical thoracoscopy, using several ports, and often combining diagnosis with treatment. VATS is contraindicated and open biopsy is preferred when the patient cannot tolerate single-lung ventilation (e.g. patient undergoing mechanical ventilation, prior contralateral pneumonectomy, or abnormal airway anatomy precluding placement of double-lumen endotracheal tube), if the pleural space contains adhesions that would prevent the safe insertion of the examining thoracoscope, and if there is insufficient expertize to deal with the complications of the procedure [105]. Adhesions may be evident preoperatively on chest radiographs or on pleural ultrasound and may lead to the decision to undertake open biopsy. Often, however, this situation is appreciated for the first time at a VATS examination, and the surgeon must therefore be ready to convert to an open procedure. Adhesions frequently result from previous pleurodesis attempts but may also follow repeated thoracentesis for diagnosis or therapy.

\section{Treatment}

\section{Indications and contraindications}

With the diagnosis of a malignant pleural effusion, palliative therapy should be considered, necessitating evaluation of the patient's symptoms, general health and functional status, and expected survival. The 
major indication for treatment is relief of dyspnoea. The degree of dyspnoea is dependent on both the volume of the effusion and the underlying condition of the lungs and pleura.

Therapeutic thoracentesis should be performed in virtually all dyspnoeic patients with malignant pleural effusions to determine its effect on breathlessness and rate and degree of recurrence. In some dyspnoeic patients with a large effusion and contralateral mediastinal shift, some clinicians may choose to proceed directly to chest tube drainage and chemical pleurodesis or thoracoscopy with talc poudrage. Rapid recurrence of the effusion dictates the need for immediate treatment; stability and absence of symptoms may warrant observation. If dyspnoea is not relieved by thoracentesis, other causes should be investigated, such as lymphangitic carcinomatosis, atelectasis, thromboembolism, and tumour embolism.

Before attempting pleurodesis, complete lung expansion should be demonstrated. Failure of complete lung expansion occurs with mainstem bronchial occlusion by tumour or trapped lung due to extensive pleural tumour infiltration. If a contralateral mediastinal shift is not observed on the chest radiograph with a large pleural effusion, or the lung does not expand completely after pleural space drainage, an endobronchial obstruction or trapped lung should be suspected and can be diagnosed with bronchoscopy or thoracoscopy, respectively. An initial pleural fluid pressure of $\leqslant-10 \mathrm{cmH}_{2} \mathrm{O}$ at thoracentesis makes trapped lung likely [43, 106, 107]. Cut-off points of $\leqslant-19 \mathrm{cmH}_{2} \mathrm{O}$ with the removal of $500 \mathrm{~mL}$ [107] of fluid and of $\leqslant-20 \mathrm{cmH}_{2} \mathrm{O}$ with the removal of $1 \mathrm{~L}$ of fluid [106] are predictive of trapped lung in the absence of endobronchial obstruction.

\section{Therapeutic thoracentesis}

Therapeutic thoracentesis may serve as the primary therapeutic modality in some patients. In patients with far advanced disease, poor performance status, and low pleural fluid $\mathrm{pH}(\mathrm{pH} \leqslant 7.2)$ relief can be provided by periodic outpatient therapeutic thoracenteses in lieu of hospitalization for more invasive and morbid procedures. Animal studies suggest that pleural effusions tend to increase the volume of the hemithorax more than they compress lung tissue [108]. It is therefore not surprising that after thoracentesis, total lung capacity (TLC) increases by approximately one-third the volume of fluid removed, and the forced vital capacity (FVC) increases by one-half the increase in TLC [109]. The improvement in FVC and TLC after thoracentesis is variable and is greatest in patients with high lung compliance.

Intrapulmonary shunt is the main mechanism underlying the arterial hypoxaemia associated with a large pleural effusion. Thoracentesis has short-term effects on pulmonary gas exchange [110]. The effect on arterial oxygen tension $\left(\mathrm{Pa}, \mathrm{O}_{2}\right)$ is variable, and it can increase, remain the same, or decrease [109-112]. After therapeutic thoracentesis, there appears to be delayed lung volume re-expansion, with or without the coexistence of minimal pulmonary oedema [113].
The volume of fluid that can be safely removed from the pleural space during a therapeutic thoracentesis is unknown. Ideally, monitoring of pleural fluid pressure during the procedure should determine that volume. If pleural fluid pressure does not decrease below $-20 \mathrm{cmH}_{2} \mathrm{O}$, fluid removal can usually be continued safely [106]. As most clinicians do not measure pleural pressure during therapeutic thoracentesis, it is recommended that only $1-1.5 \mathrm{~L}$ of fluid is removed at one sitting, as long as the patient does not develop dyspnoea, chest pain, or severe cough. When a patient with contralateral mediastinal shift on chest radiograph tolerates thoracentesis without chest tightness, cough, or dyspnoea, removal of several litres of pleural fluid is probably safe. Neither patient nor operator, however, may be aware of a precipitous decrease in pleural pressure. In patients without contralateral or with ipsilateral mediastinal shift, the likelihood of a precipitous fall in pleural pressure is increased, and either pleural pressure should be monitored during thoracentesis or only a small volume of fluid $\left(<300 \mathrm{~cm}^{3}\right)$ should be removed. In patients with ipsilateral mediastinal shift, it is unlikely that removal of pleural fluid will result in significant relief of dyspnoea, because there is either mainstem bronchial occlusion or a trapped lung. Re-expansion pulmonary oedema can occur after rapid removal of air or pleural fluid from the pleural space and is not necessarily related to the absolute level of negative pleural pressure. The mechanism of oedema is believed to be increased capillary permeability; the injury may be related to the mechanical forces causing vascular stretching during re-expansion [114] or to ischaemia-reperfusion.

\section{Chemical pleurodesis}

Chemical pleurodesis is accepted palliative therapy for patients with recurrent, symptomatic malignant pleural effusions. Various chemicals have been used in an attempt to produce pleurodesis. Adequate assessment of the efficacy of specific chemical agents has been problematic because reported trials have evaluated small numbers of patients, employed different techniques, used conflicting success criteria, and/or monitored subjects for varying periods of time. Progression of disease is variable, and death has sometimes occurred during the first month after pleurodesis. Not all chemical agents have undergone direct comparison under similar conditions in the same patient population. In some studies, adverse effects have been addressed casually, making comparisons difficult.

WALKER-RENARD et al. [115] reviewed all published articles in the English language from 1966-1992 describing patients with recurrent, symptomatic malignant pleural effusions who were treated with chemical pleurodesis. A total of 1,168 such patients were analysed for complete success of pleurodesis (defined as nonrecurrence of the effusion, as determined by clinical examination or chest radiograph) and 1,140 patients assessed for drug toxicity. Chemical 
Table 3.-Complete success rates of commonly used pleurodesis agents

\begin{tabular}{lcccl}
\hline Chemical agent & Total patients $\mathrm{n}$ & Successful $\mathrm{n}$ & Successful \% & Dose \\
\hline Talc & 165 & 153 & 93 & $2.5-10 \mathrm{~g}$ \\
Corynebacterium parvum & 169 & 129 & 76 & $3.5-14 \mathrm{mg}$ \\
Doxycycline & 60 & 43 & 72 & $500 \mathrm{mg}(\mathrm{often} \mathrm{multiple} \mathrm{doses)}$ \\
Tetracycline & 359 & 240 & 67 & $500 \mathrm{mg}-20 \mathrm{mg} \cdot \mathrm{kg}^{-1}$ \\
Bleomycin & 199 & 108 & 54 & $15-240 \mathrm{units}$ \\
\hline
\end{tabular}

Adapted from [115].

pleurodesis produced a complete response in 752 $(64 \%)$ of the 1,168 patients.

The complete success rate with fibrosing agents (nonantineoplastic drugs) was 75\% (557 of 770), compared with a complete success rate of only $44 \%$ (175 of 398) for antineoplastic agents. Talc (2.5-10 g) was the most effective agent, with a complete success rate of $93 \%$ (153 of 165 patients) (table 3) [115]. The efficacy of talc in the control of malignant pleural effusions has been found to be superior to that of bleomycin and tetracycline [116-118]. The most commonly reported adverse effects were pain and fever. Adverse reactions varied among the different agents (table 4) [115]. If the patient undergoing pleurodesis is receiving corticosteroid therapy, the drug should be stopped or the dose reduced if possible because of concerns of decreased efficacy of pleurodesis [119].

Patients selected for pleurodesis should have significant symptoms that are relieved when pleural fluid is evacuated. There should be evidence of complete re-expansion of the lung without evidence of bronchial obstruction or fibrotic trapped lung. Most commonly, pleurodesis is performed via a standard tube thoracostomy. However, some studies have reported similar success rates with small-bore (3-5 mm) catheters [120-125]. Ideally, the chest tube is directed posteriorly toward the diaphragm. Radiographical confirmation is then obtained to demonstrate complete re-expansion of the lung in evacuation of the fluid. At this point, intravenous narcotic analgesics and/or sedation are often recommended because of the pain associated with many sclerosing agents. The sclerosing agent of choice is then added to the chest tube, typically in a solution of $50-100 \mathrm{~cm}^{3}$ of sterile saline. The chest tube is then clamped for $1 \mathrm{~h}$, without rotation of the patient being required. The chest tube is then subsequently reconnected to $20 \mathrm{cmH}_{2} \mathrm{O}$ suction. It is then recommended that

Table 4. - Adverse effects of commonly used pleurodesis agents

\begin{tabular}{lccc}
\hline Chemical agent & $\begin{array}{c}\text { Total } \\
\text { patients } n\end{array}$ & $\begin{array}{c}\text { Chest pain } \\
\%\end{array}$ & $\begin{array}{c}\text { Fever } \\
\%\end{array}$ \\
\hline Talc & 131 & 7 & 16 \\
Corynebacterium parvum & 169 & 43 & 59 \\
Doxycyline & 60 & 40 & 31 \\
Tetracycline & 359 & 14 & 10 \\
Bleomycin & 199 & 28 & 24 \\
\hline
\end{tabular}

Adapted from [115]. suction be applied to the chest tube until the 24-h output from the chest tube is $<150 \mathrm{~cm}^{3}$.

Doxycycline. For many years, tetracycline was the sclerosing agent of choice. However, when it became commercially unavailable, alternative agents were investigated. Doxycycline, a tetracycline analogue, has been recommended as a replacement for tetracycline. Although there are no direct studies comparing doxycycline with tetracycline, pleurodesis studies have demonstrated clinical success rates with doxycycline that are similar to those with tetracycline (historical data), with a success rate of up to $80-85 \%$ in carefully selected patients $[120,126,127]$. Most studies have recommended the utilization of $500 \mathrm{mg}$ of doxycycline mixed with $50-100 \mathrm{~cm}^{3}$ of sterile saline $[120,127]$. As pain is the most common complication associated with doxycycline pleurodesis, narcotic analgesic and/or conscious sedation is often recommended [126].

Bleomycin. Another agent frequently recommended for pleurodesis is bleomycin. Most studies have used a dose of 60 IU of bleomycin mixed with $50-100 \mathrm{~cm}^{3}$ of sterile saline. Unlike doxycycline, bleomycin has been directly compared with tetracycline. Most of these studies demonstrated similar or higher success rates when utilizing bleomycin as a sclerosing agent, compared with tetracycline [117, 128, 129]. A direct study comparing doxycycline with bleomycin pleurodesis utilizing a small-bore catheter, demonstrated similar success rates $(72 \%$ with bleomycin, $79 \%$ with doxycycline) [120]. As stated previously, direct studies comparing talc and bleomycin have demonstrated a superior pleurodesis success rate with talc $[115,116,130]$. An important criticism of bleomycin as a sclerosing agent involves its relative expense as compared with other sclerosing agents such as talc or doxycycline [129, 131]. However, studies utilizing small-bore catheters and bleomycin have demonstrated successful pleurodesis $[120,121]$ and therefore a potential overall cost saving when factors such as hospitalization, duration, and procedure costs are included.

\section{Talc pleurodesis}

Talc from chemical supply houses is asbestos free [132], with variable particle size generally $<50 \mu \mathrm{m}$. Although talc is not packaged aseptically by the manufacturer, limitation of the number of microorganisms is a part of the specifications, and the total 
bacterial count cannot exceed 500 organisms $\cdot g^{-1}$ of talc. In one study, bacillus species were cultured from six different supplies of unsterilized talc; dry heat, $\gamma$-irradiation, and ethylene oxide gas all proved effective sterilization methods [133]. The cost of sterilizing a 5 -g packet of talc (about $10 \mathrm{~cm}^{3}$ ) is $\sim £ 3, £ 5$ or $£ 10$ for dry heat, ethylene oxide, and $\gamma$-irradiation, respectively [114]. Sterilized talc remains culture-negative on the pharmacy shelf for $>1$ yr [134].

A review of published series found a 93\% success rate (153 of 165 patients) for talc pleurodesis in the treatment of pleural effusions, the majority of them malignant [115]. Success was variably defined in these studies but was based primarily on 16 clinical criteria or radiographical findings. In some studies, complete and persistent absence of fluid was the determinant, where as in others, the lack of need for further pleural drainage was the sole criterion. Follow-up times were also variable, and in these studies, doses ranged $1-14 \mathrm{~g}$. When analysed by the method of administration, poudrage and slurry pleurodesis methods resulted in similar success rates of $91 \%$ : 418 of 461 for talc poudrage and 168 of 185 for slurry [116-118, 135-137]. In a small series of 57 patients randomized to receive talc slurry through a chest tube or talc poudrage with VATS, using $5 \mathrm{~g}$ of talc, no significant difference was found in recurrence: one of 28 with poudrage and three of 29 with slurry [138]. A large randomized multicentre trial addressing the efficacy of talc poudrage versus talc slurry is near completion in the North American Cooperative Oncology Groups.

A defined rate of clinically important complications was observed with thoracoscopic talc poudrage and no deaths were related to the procedure in a series of 360 patients [139]. A similarly low rate of complications was observed by Viallat et al. [140], who used either local anaesthesia plus conscious sedation or general anaesthesia in a two-center study that included 360 patients. Fever up to $102.4^{\circ} \mathrm{F}$ after talc pleurodesis has been reported to occur in $16-69 \%$ of patients [141]. Fever characteristically occurs $4-12 \mathrm{~h}$ after talc instillation and may last for $72 \mathrm{~h}$. Empyema has been reported with talc slurry in $0-11 \%$ of procedures, whereas talc poudrage is associated with an incidence rate of $0-3 \%$ of patients [141]. Local site infection is uncommon, and the degree of pain associated with talc has reportedly ranged from nonexistent to severe.

Cardiovascular complications such as arrhythmias, cardiac arrest, chest pain, myocardial infarction, or hypotension have been noted; whether these complications result from the procedures or are related to talc per se has not been determined. Acute respiratory distress syndrome (ARDS), acute pneumonitis, and respiratory failure have also been reported to occur after both talc poudrage and slurry [141]. It is doubtful that the method of administration (poudrage versus slurry) plays a major role in the development of respiratory failure, although the dose and particle size of talc may be important. In an experimental study using talc slurry, KenNedy et al. [142] found prominent perivascular infiltrates with mononuclear inflammation in the underlying lung, and it was speculated that mediators might spread through the pulmonary circulation after application of the sclerosing agent [142]. Other possible causes of acute respiratory failure with talc pleurodesis include sepsis due to nonsterile or endotoxin-containing talc, excessive talc dosing, active air leak, excessive periprocedure medications, severe underlying lung disease, and re-expansion pulmonary oedema.

Twenty-two to $35 \mathrm{yrs}$ after talc poudrage of pneumothorax, TLC averaged $89 \%$ of predicted in 46 patients, whereas TLC was $97 \%$ of predicted in 29 patients treated with tube thoracostomy alone [143]. None of the poudrage group developed mesothelioma over the 22- to 35-yr follow-up. Although talc poudrage may result in minimally reduced total capacity, as well as pleural thickening on chest radiography, these changes appear to be clinically unimportant. Short-term follow-up after talc poudrage for pneumothorax revealed no difference in lung function when compared with other patients who had thoracotomy without talc poudrage [144, 145]. A link between talc and cancer has been reported in those who mine and process talc [146], but this association is attributed to asbestos, which is commonly found with talc, rather than to talc itself. No increase in lung cancers was found in a group of patients who had talc pleurodesis for pneumothorax and had long-term follow-up [147].

Talc is an inexpensive and highly effective pleurodesis agent when administered by either poudrage or slurry in patients with malignant pleural effusions. The most common short-term adverse effects include fever and pain. Development of respiratory failure is reported and may be related to dose and particle size, or other factors related to its instillation [148, 149]. Investigation of this issue is ongoing and physicians and patients should be aware of a potential for respiratory failure, which has not been described with other agents. Long-term safety does not appear to be an issue with the asbestos-free product, especially in patients with malignant pleural effusions. Because the response to talc has not been studied over a wide dose range and serious adverse effects tend to occur with higher doses [150], it is recommended that no more than $5 \mathrm{~g}$ of talc be used, and that bilateral simultaneous pleurodesis not be attempted.

Talc poudrage. The most widely reported method of talc instillation into the pleural space for malignant effusion is talc poudrage, which is usually performed under thoracoscopic guidance. Talc poudrage can be performed by medical thoracoscopy under local anaesthesia with conscious sedation or by VATS.

Several technical details should be taken into account in order to achieve good pleurodesis and avoid complications. All pleural fluid should be removed before spraying talc. Removal can be easily accomplished during thoracoscopy, as air is passively entering the pleural cavity, thus creating a desirable equilibrium in pressures. Complete collapse of the lung is important, affording a good view of the pleural cavity and the opportunity to biopsy suspicious lesions and also permitting wide distribution of the talc.

Although an optimal dose of talc for poudrage has 
not been established, $\sim 5 \mathrm{~g}(8-12 \mathrm{~mL})$ is usually recommended for malignant effusions. After talc insufflation, repeat inspection of the pleural cavity should be done to ensure that the powder has been evenly distributed over the pleural surface.

An $8-11 \mathrm{~mm}$ chest tube should always be inserted. Graded and progressive suction should be applied and maintained until the amount of fluid aspirated per day is $<100 \mathrm{~mL}$. Air leak can occur in patients with necrotic tumour nodules in the visceral pleura, especially those with prior chemotherapy, even if no biopsies of this area have been taken.

On average, reported success with talc poudrage is $>90 \%$ but, as previously noted, reliable guidance on doses remains elusive, and definitions of success have not been standardized [151, 152].

Talc slurry. Talc slurry is also an effective pleurodesis agent in malignant effusions [136, 138]. Potential disadvantages of slurry include lack of uniform distribution, accumulation in dependent areas of the pleural space possibly leading to incomplete pleurodesis and loculations, and decreased direct contact time with the pleural surface due to the liquid suspension with subsequent decrease in effectiveness.

The slurry is made by mixing talc with normal saline and gently agitating. Various volumes of saline have been used, ranging from 10-250 $\mathrm{mL}$ [136, 138]. The pleurodesis technique is the same as for the soluble chemical agents [153]. It is recommended that administration of small doses of an intravenous narcotic and anxiolytic-amnestic agent before the procedure. The chest should be drained as completely as possible by tube thoracostomy. Standard chest tubes $(6-8 \mathrm{~mm})$ or small-bore catheters $(3-4 \mathrm{~mm})$ have been used successfully for talc slurry pleurodesis $[123,124]$. A dose of $4-5 \mathrm{~g}$ of talc in $50 \mathrm{~mL}$ of normal saline should be instilled through the chest tube when the radiograph demonstrates an absence or minimal amount of pleural fluid and complete lung expansion. The chest tube should be clamped for $1 \mathrm{~h}$ after talc slurry instillation. It is unclear whether talc slurry disperses as rapidly throughout the pleural space, compared with tetracycline $[154,155]$. Therefore, patient rotation is recommended until definitive studies are available. After unclamping of the chest tube, the patient should be maintained on $-20 \mathrm{cmH}_{2} \mathrm{O}$ suction; the chest tube should be removed when the 24-h tube drainage is $<100-150 \mathrm{~mL}$. If, after $48-72 \mathrm{~h}$, chest tube drainage remains excessive $\left(>250 \mathrm{~mL} \cdot 24 \mathrm{~h}^{-1}\right)$, talc instillation, at the same dose used initially, should be repeated.

\section{Treatment of pleurodesis failure}

Initial failure of pleurodesis can occur as a result of suboptimal techniques or inappropriate patient selection (e.g. a patient with a trapped lung or mainstem bronchial occlusion). Recurrence after pleurodesis is unusual with talc but does occur occasionally, usually soon after attempted pleurodesis.

When initial pleurodesis for malignant pleural effusion fails, several alternatives may be considered.
Repeat pleurodesis may be performed either with instillation of sclerosants through a chest tube or by thoracoscopy and talc poudrage. Repeat thoracentesis would be the choice for a terminal patient with short expected survival. Pleuroperitoneal shunting or pleuroectomy may be suitable for patients whose clinical condition is reasonably good and who have experienced pleurodesis failure. Other alternatives in failed pleurodesis include tube drainage into a bag.

\section{Other treatments}

Systemic therapy. In patients with symptomatic malignant pleural effusions due to tumours likely to respond to chemotherapy, such as small-cell lung cancer, systemic treatment should be started if no contraindications exist and it may be combined with therapeutic thoracentesis or pleurodesis. Neoplasms that tend to be chemotherapy responsive include breast cancer (hormone treatment may also be appropriate), small-cell lung cancer, and lymphoma. Effusions associated with prostate, ovarian, thyroid, and germcell neoplasms may also be chemotherapy responsive. When systemic treatment options are unavailable or contraindicated, or systemic treatment is or has become ineffective, local therapy such as pleurodesis may be applied.

Surgery. Major surgical procedures, such as parietal pleurectomy, decortication, or pleuropneumonectomy, performed alone, have proved to provide neither superior palliation nor prospects for cure, compared with pleurodesis alone. Surgical palliation may, however, be achieved with talc pleurodesis and/or the insertion of a pleuroperitoneal shunt [156]; such approaches may be undertaken by VATS or limited thoracotomy. Pleurodesis may fail if there is a cortex of malignant tissue covering the pleural surfaces. The cortex may be removable by converting to an open thoracotomy, and pleurodesis may then prove possible. This procedure has a reported perioperative mortality of $12 \%$, and therefore patient selection is important [157].

If expansion of the lung is inadequate after removal of an effusion due to a cortex of malignant tissue or fibrosis, a pleuroperitoneal shunt should be inserted. Such a situation may be suggested by lack of mediastinal shift on perioperative radiographs or may be seen only at surgery. A shunt should be readily available when undertaking such treatment [156]. Shunt complications, chiefly occlusion, will occur in $12 \%$ of patients, and such occlusion is treated by shunt replacement [158], unless infection is confirmed. In that case, long-term drainage with a chest tube is indicated. The possibility of inducing peritoneal seeding with a pleuroperitoneal shunt is a potential risk but has not been convincingly documented, and in this group of patients, there is no established alternative treatment.

Intrapleural therapy. When the malignancy is localized in the pleural cavity, intrapleural chemotherapy may 
treat the underlying neoplasm in addition to controlling the effusion $[159,160]$. To obtain maximal anticancer activity with minimal systemic side effects, however, a high intrapleural concentration with minimal systemic spread of the antineoplastic agent is required. To meet these requirements, several authors have proposed including cytostatic drugs in poly-L-lactic acid microspheres [161].

Active cytokines may be instilled directly into the pleural space. Interleukin-2 (IL-2), interferon- $\beta$, and interferon- $\gamma$ (IFN- $\gamma)$ have been tried, with variable success, in the treatment of malignant pleural effusion and mesothelioma [162-167]. It is not clear whether the observed responses are due to intrinsic sclerosing activity or, instead, to an immunological effect such as an increased natural killer cell population. Thus, the results of phase II intrapleural therapy studies to date have been inconclusive, because most of these evaluations have been based on radiographic findings or cytological examination of the pleural fluid. There are few studies using endoscopic staging for malignancy involving the pleura [164].

Other potential candidates for intrapleural therapy include patients with malignant effusion and an unknown primary tumour. Many of these tumours probably originate from small subpleural carcinomas [168], a condition sometimes termed "pseudomesotheliomatous carcinoma of the lung." Such carcinomas demonstrate a characteristic growth pattern of peripheral adenocarcinoma of the lung with extensive pleural growth and little peripheral parenchymal involvement and, therefore, may be ideal targets for attempts at local therapy.

\section{Malignant pleural effusions in specific diseases}

\section{Lung carcinoma}

Lung carcinoma is the leading cause of malignant pleural effusions. Malignant effusions are observed in $7-15 \%$ of all bronchogenic carcinomas at some time during the course of the illness [2, 3, 13, 169]. Effusions occur with all histological types, most frequently with adenocarcinoma [12, 87]. The published occurrences have been obtained by evaluation of standard chest radiographs and would undoubtedly be more numerous if ultrasound and CT were used to define the presence of effusions.

The presence of pleural effusion typically signals an advanced stage of disease and is therefore associated with poor prognosis. In some cases, however, the pleura itself is not involved in tumour growth. These accompanying paramalignant effusions are due to postobstructive pneumonia or atelectasis, venous obstruction by tumour compression, or lymphatic obstruction by mediastinal lymph nodes, and are not associated with direct pleural involvement. Such patients are few in number, but if pleural cytology is negative, the clinician should explore additional diagnostic avenues, including CT, pleural biopsy, medical thoracoscopy, or surgical procedures (VATS/open biopsy) [170].

The prognosis of patients with nonsmall cell lung cancer and paramalignant effusion is comparable to that for those in the same stage without pleural effusion [87, 169]. This is also true for small-cell lung cancers where there is limited disease, with or without pleural effusion. Pleural effusions with positive cytology for small-cell lung carcinoma constitute a worse prognosis for patients with otherwise limited disease without malignant effusion [171]. In nonsmall cell lung cancer at an advanced, inoperable stage, talc pleurodesis should be considered [172, 173]. With a large pleural effusion and suspicion of tumour obstruction of the central bronchi, suggested by absence of contralateral mediastinal shift and supported by CT findings, bronchoscopy should be performed first and the obstruction removed (e.g. by laser), permitting lung re-expansion after fluid removal.

Systemic chemotherapy is the treatment of choice in small-cell lung cancer, where the pleural effusion often resolves without the need for local treatment [171]. Pleurodesis is indicated only when chemotherapy is contraindicated or ineffective.

\section{Mesothelioma}

Median survival of patients with mesothelioma is 6-18 months. Unfortunately, the clinical course is not significantly affected by current therapeutic manoeuvres. Most commonly, the cause of death is local extension and/or respiratory failure. Distant metastatic disease resulting from haematogenous spread may also be present, typically at the end stage [174-176].

A poor prognosis is indicated by histological type (i.e. sarcomatous or mixed histology), thrombocytosis, fever of unknown origin, age $>65 \mathrm{yrs}$, and poor Karnofsky index. A more favourable prognosis is associated with epithelial histology, stage I disease (particularly if the disease is localized to the parietal pleura), absence of chest pain, and the presence of symptoms for $<6$ months before diagnosis [90, 177].

Single-modality therapy for mesothelioma has been disappointing. High-dose external beam irradiation, intrapleural administration of radioactive isotopes, and various chemotherapeutic regimens have shown no significant effect on overall survival. Nor is there proof that a surgical approach alone improves patient survival. To be curative, resection must include the pleura (in stage Ia), lung (in stage Ib, II, III) and, often, the diaphragm, the pericardium, and a portion of the chest wall (extrapleural pneumonectomy). In spite of careful selection (age $<60$ yrs, early-stage disease, favourable epithelial type), the 5-yr survival rate is only $11 \%[175,178,179]$.

In light of this outlook, there has been ongoing focus on multimodality therapy $[180,181]$. A combination of parietal pleurectomy with postoperative intrapleural therapy and/or external beam irradiation resulted in median survival of 22.5 months and a 2-yr survival rate of $41 \%$ in a selected group of 27 patients, predominantly with the epithelial subtype [181].

Early-stage disease appears to be the key factor in treatment success. In stage I, and especially in stage Ia 
(without involvement of the visceral pleura), the disease is still intrapleural and thus can be treated by intrapleural therapy. Although they are still not available on the market, there have been promising results with interferon and IL-2 intrapleural injections made via an implantable port $[165,166,182]$. The best indication for intrapleural treatment is stage $\mathrm{Ia}$ (or $\mathrm{Ib}$ ) in epithelial-type mesothelioma, with nodules or thickening $\leqslant 5 \mathrm{~mm}$, in patients whose general status is still good.

In patients with stage II and III mesothelioma, there is no randomized study showing the superiority of any one treatment compared with another; the practitioner has a choice between two alternatives. One is a multimodality treatment, including radical surgery, radiation therapy, and chemotherapy. The result of this approach is largely related to the expertize and experience of the involved surgeons, so that a surgical mortality rate as low as possible (range, $4-8 \%$ ) is maintained. The second is medical treatment: talc pleurodesis if necessary, preventive radiation therapy, and combined chemotherapy [183]. In patients with stage IV disease, only conservative, palliative treatment to control pain is indicated.

\section{Breast carcinoma}

Breast carcinoma is the second-ranking cause of malignant pleural effusion. About $7-11 \%$ of patients with breast carcinoma develop a malignant pleural effusion during the course of the disease [4-6]. In 43\% of those patients, the effusion is the first symptom of metastatic disease [6]; the time from initial diagnosis until the development of pleural effusion averages 41.5 months (range, 0-246 months) [137]. In a review of seven autopsy series, the pleura was affected in about one-half of 2,050 cases (range, 36-65\%) [10]. Higher tumour stages at the time of initial diagnosis [136], as well as chest wall recurrences [6], were associated more often with pleural effusion.

Besides the rare direct invasion through the chest wall, the pathogenesis of pleural involvement in breast carcinoma is through either lymphatic or haematogenic spread. FENTIMAN et al. [137] found, in 99 patients with unilateral breast tumours and pleural effusions, that $50 \%$ of the effusions were ipsilateral, $40 \%$ were contralateral, and $10 \%$ were bilateral; RAJU and KARDINAL [184], however, observed ipsilateral effusions in 85 of 122 patients.

The yield from cytological examination of the effusion is usually higher than with other tumours [185], so that pleural biopsy or medical thoracoscopy is rarely indicated. Determination of hormone receptor status in the pleural tissue may be helpful in guiding hormonal therapy [94].

In differential diagnosis, it is important to exclude pleural effusions caused by postoperative radiotherapy, which usually occur during the first 6 months and are commonly accompanied by radiation pneumonitis; they usually resolve spontaneously over several months [186].

Recommended treatment of metastatic pleural effusion with breast carcinoma differs from that for other tumour types. Chemotherapy with cytotoxic agents and/or hormones may be effective [137, 187, 188]. If those approaches do not relieve symptoms, local treatment options must be considered.

Median survival after the appearance of metastatic pleural effusions in one series of 105 patients was 13 months (range, 0-72 months), without taking into consideration the different treatment modalities and other factors [137]. RAJU and KARDINAL [184], in their study of 122 patients, observed a median survival of only 6 months after the onset of pleural effusion. Survival times are undoubtedly strongly related to the presence of additional metastatic manifestations; in another study, median survival of patients whose pleural effusions were the only evidence of recurrent malignancy $(\mathrm{n}=10)$ was 48 months, whereas median survival of those with other evident sites of disseminated disease $(n=35)$ was only 12 months [188].

\section{Lymphoma, leukaemia, and multiple myeloma}

Approximately $10 \%$ of malignant pleural effusions are due to lymphoma. According to reports in the early 1940s, in Hodgkin's disease, pleural effusions develop in $16 \%$ of patients and pleural thickening in $7 \%$; the figures were, $15 \%$ and $11 \%$ in non-Hodgkin's lymphoma and $2 \%$ and $4 \%$ in leukaemia, respectively [11]. Later observations have differed. Of 4,500 Mayo Clinic patients with lymphoma, only $7 \%$ had pleural effusions [7]. In other studies, the incidence of effusion in Hodgkin's disease has been variously reported as $5 \%$ [189], $28 \%$, or $33 \%$ [190].

Pleural effusion usually develops in the later stages of the disease, with dyspnoea the chief symptom in $63 \%$ [9], and occasionally it may be the only symptom [191]. The main cause of effusion, which may be unilateral or bilateral, is obstruction of the lymphatic drainage by enlarged mediastinal lymph nodes in Hodgkin's disease and by direct tumour infiltration of the parietal or visceral pleura in non-Hodgkin's lymphoma [11, 192-194]. The effusion is usually an exudate but may occasionally have transudative characteristics. Effusions may be serous, haemorrhagic, or chylous [194, 195]; non-Hodgkin's lymphoma is the most common cause of chylothorax [195, 196].

The cytological yield lies between 31-55\% [197], with the lowest yield reported in Hodgkin's disease [193, 194]. Chromosome analysis has high sensitivity, about $85 \%$ [198]; results obtained by medical thoracoscopy are superior $[58,191]$. Clonality can also be demonstrated via flow cytometry. Effusions can also result from radiation of the mediastinum or from obstruction of lymphatic drainage of the pleural space due to mediastinal fibrosis, constrictive pericarditis, or superior vena caval obstruction. This may occur a year or two after radiotherapy [199] and may also result in a chylous effusion [200]. Average survival time after the first thoracentesis is short, 6 or 7 months, but there may be a wide range [7, 41]. The presence of malignant cells in the effusion is associated with a poor prognosis.

The treatment of choice is systemic chemotherapy. Pleurodesis by talc poudrage combined with 
parenteral alimentation, in order to reduce chyle production, may be necessary when chemotherapy fails [201]. Mediastinal radiation may be useful when there is mediastinal node involvement and may be effective in chylothorax [195]. In patients with chylothorax, pleuroperitoneal shunt may be a good approach in failed therapy, as it can recirculate the chyle [202].

Multiple myeloma is an infrequent cause of malignant pleural effusion, which occurs in $\sim 6 \%$ of cases [189, 203]. High pleural protein values, in the range of $8-9 \mathrm{~g} \cdot \mathrm{L}^{-1}$, are suggestive of this diagnosis. Electrophoresis and immunoelectrophoresis of pleural fluid may be diagnostically characteristic [204]. Infiltration of the chest wall is usually present, due to invasion from adjacent skeletal lesions (ribs, sternum, and vertebrae), but pleuropulmonary infiltration may also originate from soft tissue plasmocytoma of the chest wall or from direct involvement. With pleural immunocytoma from Waldenström's macroglobulinemia, pleural effusion is a rare manifestation [205].

\section{Factors affecting prognosis}

According to several studies, the best correlation for pleurodesis outcome and overall survival are pleural fluid $\mathrm{pH}$ and glucose [41-45]. However, a meta-analysis of $>400$ patients found a poor predictive value for success of pleurodesis [52]. The patient's general health status and tumour type should be considered in deciding appropriateness for pleurodesis. Because pleural fluid glucose is usually more sensitive to fluctuations in serum than $\mathrm{pH}$, the predictive value of glucose is lower than that of $\mathrm{pH}$. In one prospective study, measurement of the elastance of the pleural space was associated with pleurodesis outcome [107].

Quality of life of patients with malignant effusions should be evaluated with regard to those symptoms that are related to the effusion itself. Relief of dyspnoea remains the primary objective for most patients. Ideally, therapy should minimize discomfort, as well as limit hospitalization time, in these patients with an often limited life span. However, an important aspect in any treatment is prevention of reoccurrence of the symptomatic effusion. Finally, pain relief is another important quality-of-life issue, which must be addressed. This is particularly true for patients with mesothelioma, whose primary complaint is often pain instead of dyspnoea.

\section{Future directions for research}

\section{Definitions of success or failure of pleurodesis}

Uniform criteria for evaluating the results of pleurodesis in future studies are badly needed. The following definitions are proposed:

Completely successful pleurodesis. Long-term relief of symptoms related to the effusion, with absence of fluid reaccumulation on chest radiographs until death.
Partially successful pleurodesis. Diminution of dyspnoea related to the effusion, with only partial reaccumulation of fluid $(<50 \%$ of the initial radiographic evidence of fluid), with no further therapeutic thoracenteses required for the remainder of the patient's life.

Failed pleurodesis: Lack of success (as defined earlier). Comparative studies of different pleurodesis techniques should evaluate outcomes using time-toevent analyses censoring patients who are lost to follow-up. Data should be reported with and without inclusion of patients who die within 1 month of pleurodesis.

\section{Prospects for clinical studies}

There are few data on which the clinician can confidently rely on, making important therapeutic decisions in the management of malignant pleural effusions. Most urgently needed are well-designed prospective studies that will: 1) Determine the course of small, asymptomatic malignant pleural effusions with and without treatment. Because late pleurodesis attempts are more likely to fail than earlier interventions, it might be suggested that pleurodesis simply be performed at an early stage, once the malignant nature of the effusion is known. Many of these patients, however, have few symptoms attributable to the effusion itself and are not likely to seek relief or treatment for it. Prospective studies are therefore needed to provide reliable management guidelines. 2) Assess talc slurry pleurodesis versus talc poudrage via thoracoscopy, with particular attention to optimal dosage, the use of intrapleural analgesics such as lidocaine, and patient positioning during talc slurry procedures. 3) Explain the systemic complications and side effects of talc pleurodesis, especially potential triggering of coagulation in the systemic circulation. Because it is likely that this untoward event occurs with other sclerosing agents as well, such information would be useful in developing preventive measures. 4) Explore and clarify the potential role of intrapleural therapeutic interventions, including not only chemotherapeutic agents but also such immune modulators as cytokines and interferon. As observed in the earlier discussion of this topic, employment of this modality has been largely hit-and-miss; randomized studies are needed to determine optimal application of agents, both singly and in combination, and the effect of various approaches on survival. 5) Identify dependable tumour-related markers of malignant pleural effusion. Markers that would help the clinician differentiate, for example, between reactive mesothelial cells, mesotheliomas, and metastatic adenocarcinomas would be especially valuable.

\section{Gene therapy}

In the absence of other effective, nontoxic therapies for malignant mesothelioma, several groups of investigators have turned to the newly evolving technology of gene therapy for new treatment modalities [206, 207]. 
One approach is the intrapleural administration of replication-deficient recombinant adenovirus (rAd) that has been genetically engineered to contain the herpes simplex virus thymidine kinase gene (HSV $t k$ ) [206]. It is hoped that delivery of rAdHSV $t k$ directly into the pleural cavity of patients with mesothelioma will transduce the tumour cells, enabling them to express viral thymidine kinase and conveying sensitivity to the normally nontoxic antiviral drug ganciclovir. A phase I dose escalation clinical trial of adenovirus-mediated intrapleural HSV $t k$-glanciclovir gene therapy demonstrated that the HSV tk gene is well tolerated and results in detectable gene transfer when delivered at high doses. Further development of therapeutic trials for the treatment of localized malignancy is warranted [206, 207].

\section{Cellular basis of malignant effusions and pleurodesis}

Pleural metastases with malignant effusions are common to many neoplasms, but the mechanisms of localization to the pleura remain poorly understood. Important processes in the formation of pleural metastases (e.g. adhesion, migration, propagation, and angiogenesis) are likely mediated via mesothelial cell-neoplastic cell interactions. Although mechanisms by which neoplastic invasiveness and metastases have been extensively studied, the particular intracellular events that lead to pleural metastases are poorly understood. Many systems may influence remodelling of the neoplastic stroma and neoplastic growth in the pleural compartment. In particular, the procoagulant and fibrinolytic systems have been linked to the spread of malignant mesothelioma [208, 209]. The urokinaseurokinase receptor system has been shown to relate to the invasiveness of malignant mesothelioma cells [210, 211], recapitulating the findings in several other types of cancer. Other systems are no doubt crucial to the development and propagation of pleural malignancies and these remain to be elucidated. Understanding the mechanisms propelling metastases to the pleura and their growth is essential if effective therapy is to be developed.

Instillation of a sclerotic agent into the pleural space of a patient with malignant pleural disease involves intimate and immediate contact of the sclerosing agent with both normal mesothelial cells lining the surface of the pleural cavity and the invading malignant cells. Rapid changes in the pleural fluid cellular and cytokine milieu ensue, leading to either success or failure of pleurodesis. The balance of factors that predispose the patient for success or failure of pleurodesis needs to be clearly defined.

Several sclerotic agents, including some nonchemotherapeutic agents, may have a direct effect on the malignant tumour cells, such as initiation of the events leading to programmed cell death (apoptosis) of the tumour cell.

\section{References}

1. Rodriguez-Panadero F, Borderas Naranjo F, LopezMejias J. Pleural metastatic tumours and effusions: frequency and pathogenic mechanisms in a postmortem series. Eur Respir J 1989; 2: 366-369.

2. Cohen S, Hossain S. Primary carcinoma of the lung: a review of 417 histologically proved cases. Dis Chest 1966; 49: 626-629.

3. Emerson GL, Emerson MS, Sherwood CE. The natural history of carcinoma of the lung. $J$ Thorac Surg 1959; 37: 291-304.

4. Apfelstaedt JP, Muller AG. Breast cancer complicated by pleural effusion. J Surg Oncol 1995; 58: 173-175.

5. Kreisman $\mathrm{H}$, Wolkove $\mathrm{N}$, Schwartz Finkelstein $\mathrm{H}$, Cohen C, Margolese R, Frank H. Breast cancer and thoracic metastasis: review of 119 patients. Thorax 1983; 38: 175-179.

6. Weichselbaum R, Marck A, Hellman S. Pathogenesis of pleural effusion in carcinoma of the breast. Int J Radiat Oncol Biol Phys 1977; 2: 963-965.

7. Weick JK, Kiely JM, Harrison EG, Carr DT, Scanlon PW. Pleural effusion in lymphoma. Cancer 1973; 31: 848-853.

8. Stenbygaard LE, Olsen JE. Metastatic pattern at autopsy in non-resectable adenocarcinoma of the lung. Acta Oncol 1997; 36: 301-306.

9. Stenbygaard LE, Sorensen JB, Olsen JE. Metastatic pattern in adenocarcinoma of the lung. Thorac Cardiovas Surg 1995; 110: 1130-1135.

10. Lee YTN. Breast carcinoma: pattern of metastasis at autopsy. J Surg Oncol 1983; 23: 175-180.

11. Vieta JO, Craver LF. Intrathoracic manifestations of the lymphomatoid diseases. Radiology 1943; 37: 138159.

12. Chernow B, Sahn SA. Carcinomatous involvement of the pleura: an analysis of 96 patients. Am J Med 1977; 63: 695-702.

13. Johnston WW. The malignant pleural effusion: a review of cytopathological diagnoses of 584 specimens from 472 consecutive patients. Cancer 1985; 56: 905909.

14. Hsu C. Cytologic detection of malignancy in pleural effusion: a review of 5,255 samples from 3,811 patients. Diag Cytopathol 1987; 3: 8-12.

15. Prakash UBS, Reiman HM. Comparison of needle biopsy with cytologic analysis for the evaluation of pleural effusions: analysis of 414 cases. Mayo Clin Proc 1985; 60: 158-164.

16. Molengraft FL, Vooijs GP. The interval between the diagnosis of malignancy and the development of effusions, with reference to the role of cytologic diagnosis. Acta Cytol 1988; 32: 183-187.

17. Cancer statistics 1997. CA Cancer J Clin 1997; 47: 812.

18. Marel M, Zrustova M, Stasny B, Light RW. The incidence of pleural effusion in a well-defined region: epidemiologic study in central Bohemia. Chest 1993; 104: 1486-1489.

19. Valdes L, Alvarez D, Valle JM, Pose A, SanJose E. The aetiology of pleural effusions in an area with high incidence of tuberculosis. Chest 1996; 109: 158-162.

20. Meyer PC. Metastatic carcinoma of the pleura. Thorax 1966; 21: 437-443.

21. Andrews BS, Arora NS, Shadforth MF, Goldberg SK, Davis JS. The role of immune complexes in the pathogenesis of pleural effusions. Am Rev Respir Dis 1981; 124: 115-120.

22. Sahn SA. Pleural diseases related to metastatic malignancies. Eur Respir J 1997; 10: 1907-1913.

23. Estenne M, Yernault JC, DeTroyer A. Mechanism of 
relief of dyspnoea after thoracentesis in patients with large pleural effusions. Am J Med 1983; 74: 813-819.

24. Tammilebto L, Maasilita P, Kostianen S, Appelqvist P, Holsti LR, Mattson K. Diagnosis and prognostic factors in malignant pleural mesothelioma: a retrospective analysis of sixty-five patients. Respiration 1992; 52: 129-135.

25. Maher GG, Berger HW. Massive pleural effusions: malignant and nonmalignant causes in 46 patients. $\mathrm{Am}$ Rev Respir Dis 1972; 105: 458-460.

26. O'Donovan PB, Eng P. Pleural changes in malignant pleural effusions: appearance on computed tomography. Cleve Clin J Med 1994; 61: 127-131.

27. Grogan DR, Irwin RS, Channick R. Complications associated with thoracentesis: a prospective randomized study comparing three different methods. Arch Intern Med 1990; 150: 873-877.

28. Patz EF, Shaffer K, Piwnica-Worms DR, Jochelson M, Sugarbaker DJ, Pugatch RD. Malignant pleural mesothelioma: value of $\mathrm{CT}$ and MRI imaging in predicting resectability. Am J Roentgenol 1992; 159: 961-966.

29. Carlsen SE, Bergin CJ, Hoppe RT. MR imaging to detect chest wall and pleural involvement in patients with lymphoma: effect on radiation therapy planning. Am J Roengenol 1993; 160: 191-195.

30. Bittner RC, Felix R. Magnetic resonance (MR) imaging of the chest: state of the art. Eur Respir $J$ 1998; 11: 1392-1404.

31. Benard F, Sterman D, Smith RJ, Kaiser LR, Albelda SM, Alavi A. Metabolic imaging of malignant pleural mesothelioma with fluorodeoxyglucose positron emission tomography. Chest 1998; 144: 713-722.

32. McVay PA, Toy PTCY. Lack of increased bleeding after paracentesis and thoracentesis in patients with mild coagulation abnormalities. Transfusion 1991; 31: 164-717.

33. Light RW, MacGregor Ml, Luchsinger PC, Ball WC. Pleural effusions: the separation of transudates and exudates. Ann Intern Med 1972; 77: 507-513.

34. Heffner JE, Brown LK, Barbieri CA. Diagnostic value of tests that discriminate between exudative and transudative pleural effusions. Chest 1997; 111: 970 980.

35. Clarkson B. Relationship between cell type, glucose concentration, and response to treatment in neoplastic effusions. Cancer 1964; 17: 914-928.

36. Roth BJ, O'Meara TF, Cragun WH. The serumeffusion albumin gradient in the evaluation of pleural effusions. Chest 1990; 98: 546-554.

37. Light RW, Erozan YS, Ball WC. Cells in pleural fluid: their value in differential diagnosis. Arch Intern Med 1973; 132: 854-860.

38. Yam LT. Diagnostic significance of lymphocytes in pleural effusions. Ann Intern Med 1967; 66: 972-982.

39. Adelman M, Albelda SM, Gottilieb J, Haponik EF. Diagnostic utility of pleural eosinophilia. Am J Med 1984; 77: 915-920.

40. Rubins JB, Rubins HB. Aetiology and prognostic significance of eosinophilic pleural effusions. Chest 1996; 110: 1271-1274.

41. Sahn SA, Good JT Jr. Pleural fluid $\mathrm{pH}$ in malignant effusions: diagnostic, prognostic, and therapeutic implications. Ann Intern Med 1988; 108: 345-349.

42. Sanchez-Armengol A, Rodriguez-Panadero F. Survival and talc pleurodesis in metastatic pleural carcinoma, revisited. Chest 1993; 104: 1482-1485.
43. Rodriguez-Panadero F, Lopez-Mejias L. Low glucose and $\mathrm{pH}$ levels in malignant effusions; diagnostic significance and prognostic value in respect to pleurodesis. Am Rev Respir Dis 1989; 139: 663-667.

44. Good JT, Taryle DA, Sahn SA. The pathogenesis of low glucose, low $\mathrm{pH}$ malignant effusions. Am Rev Respir Dis 1985; 131: 737-741.

45. Rodriguez-Panadero F, Lopez-Majias L. Survival time of patients with pleural metastatic carcinoma predicted by glucose and $\mathrm{pH}$ studies. Chest 1989; 95: 320-324.

46. Foresti V, Scolari N, Villa A, Parisio E, De Filippo G, Guareschi G. Malignant pleural effusions: meaning of pleural-fluid $\mathrm{pH}$ determination. Oncology 1990; 47: 62-64.

47. Foresti V. Intrapleural Corynebacterium parvum for recurrent malignant pleural effusions. Respiration 1995; 62: 21-26.

48. Martinez-Moragon E, Aparicio J, Sanchis J, Merendez R, Cruz Rogado M, Sanchiz F. Malignant pleural effusions: prognostic factors for survival and response to chemical pleurodesis in a series of 120 cases. Respiration 1998; 65: 108-113.

49. Aelony Y, King RR, Boutin C. Thoracoscopic talc poudrage in malignant pleural effusions: effective pleurodesis despite low pleural pH. Chest 998: 113: 1007-1012.

50. Bilaceroglu S, Cagirici U, Permin K, Ozacar R. Corynebacterium parvam pleurodesis and survival is not significantly influenced by pleural $\mathrm{pH}$ and glucose level. Monaldi Arch Chest Dis 1998; 53: 14-22.

51. Heffner JE, Nietert PJ, Barbieri C. Pleural fluid $\mathrm{pH}$ as a predictor of survival for patients with malignant pleural effusions. Chest 2000; 117: 79-86.

52. Heffner JE, Nietert PJ, Barbieri C. Pleural fluid $\mathrm{pH}$ as a predictor of pleurodesis failure. Chest 2000; 117: 8795.

53. Burrows CM, Mathew WC, Colt HG. Predicting survival in patients with recurrent symptomatic malignant pleural effusions. Chest 2000; 117: 73-78.

54. Joseph J, Vuney S, Beck P, Strange C, Sahn S, Basran GS. A prospective study of amylase-rich pleural effusions with special reference to amylase isoenzyme analysis. Chest 1992; 102: 1455-1459.

55. Krammer MR, Saldana MJ, Cepro RJ, Pitchenik AK. High amylase in neoplasm-related pleural effusion. Ann Intern Med 1989; 10: 567-569.

56. Hillderdal G, Lindqvist U, Engstrom-Laurent A. Hyaluronan in pleural effusions and in serum. Cancer 1991; 67: 2410-2414.

57. Starr RL, Sherman ME. The value of multiple preparations in the diagnosis of malignant pleural effusions. Acta Cytol 1991; 35: 533-537.

58. Loddenkemper R, Grosser H, Gabler A, Mai J, Preussler H, Brandt HJ. Prospective evaluation of biopsy methods in the diagnosis of malignant pleural effusions: intrapatient comparison between pleural fluid cytology, blind needle biopsy and thoracoscopy. Am Rev Respir Dis 1983; 127: Suppl. 4, 114.

59. Rijken A, Dekker A, Taylor S, Hoffman P, Blank M, Krause J. Diagnostic value of DNA analysis in effusions by flow cytometry and image analysis. $\mathrm{Am}$ J Clin Pathol 1991; 95: 6-12.

60. Mentintas M, Ozdemir N, Solak M, et al. Cheromosome analysis in pleural effusions: efficiency of this method in the differential diagnosis of pleural effusions. Respiration 1994; 61: 330-335. 
61. Sheibani K, Esteban J, Bailey A, Battifora H, Wiess L. Immunopathologic and molecular studies as an aid to the diagnosis of malignant mesothelioma. Hum Pathol 1992; 23: 107-116.

62. Shield PW, Callan JJ, Devine PL. Markers for metastatic adenocarcinoma in serous effusion specimens. Diag Cytol 1994; 11: 237-245.

63. Singh HK, Silverman JF, Berns L, Haddad MG, Park HK. Significance of epithelial membrane antigen in the work-up of problematic serous effusions. Diag Cytopathol 1995; 13: 3-7.

64. Mezger J, Stotzer O, Schilli G, Bauer S, Wilmanns W. Identification of carcinoma cells in ascitic and pleural fluid: comparison of four panepithelial antigens with carcinoembryonic antigen. Acta Cytol 1992; 36: 758 781.

65. Chen CJ, Chang SC, Tseng HH. Assessment of immunocytochemical and histochemical stainings in the distinction between reactive mesothelial cells and adenocarcinoma cells in body effusions. Chin Med J 1994; 54: 149-155.

66. Ghosh AK, Springs Al, Taylor-Papadimtriou J, Mason DY. Immunocytochemical staining of cells in pleural and peritoneal effusions with a panel of monoclonal antibodies. J Clin Pathol 1983; 36: 1154 1164.

67. Athanassiadou $\mathrm{P}$, Athanassiades $\mathrm{P}$, Lazaris $\mathrm{D}$, Kyrkou K, Petrakakou E, Aravantinos D. Immunocytochemical differentiation of reactive mesothelial cells and adenocinoma cells in serous effusions with the use of CEA and fibronectin. Acta Cytol 1994; 38: 718-722.

68. Maguire B, Whitaker D, Carrello S, Spagnolo D. Monoclonal antibody Ber-EP4: its use in the differential diagnosis of malignant mesothelioma and carcinoma in cell blocks of malignant effusions and FNA specimens. Diag Cytopathol 1994; 10: 130-134.

69. Yang PC, Luh KT, Kuo SH, Wu CW. Immunocytochemistry and ELISA quantitation of muan for diagnosis of malignant pleural effusions. Am Rev Respir Dis 1992; 164: 1571-1575.

70. Kortsik CS, Werner P, Freudenberg N, et al. Immunocytochemical characterization of malignant mesothelioma and carcinoma metastatic to the pleura: IOB3 - a new tumor marker. Lung 1995; 173: 79-87.

71. Shijubo N, Honda Y, Fujishima T, et al. Lung surfactant protein-A and CEA in pleural effusions due to lung adenocarcinoma and malignant mesothelioma. Eur Respir J 1995; 8: 403-406.

72. Poe RH, Israel RH, Utell MJ, Hall WJ, Greenblatt DW, Kallen MC. Sensitivity, specificity, and predictive values of closed pleural biopsy. Arch Intern Med 1984; 144: 325-328.

73. Escudero BC, Garcia CM, Cuesta CB, et al. Cytological and bacteriologic analysis of fluid and pleural biopsy specimens with Cope's needle. Arch Intern Med 1990; 150: 1190-1194.

74. Beauchamp HD, Kundra NK, Aranson R, Chong F, MacDonnell KF. The role of closed pleural needle biopsy in the diagnosis of malignant mesothelioma of the pleura. Chest 1992; 102: 1110-1112.

75. Canto A, Rivis J, Saumench J, Morera R, Moya J. Points to consider when choosing a biopsy method in cases of pleurisy of unknown ongin. Chest 1983; 84: 176-179.

76. Sahn SA. Thoracentesis and pleural biopsy. In: Shelhamer J, Pizzo PA, Parillo JE, Masur H, eds.
Respiratory disease in the immunosuppressed host. Philadelphia, J.B. Lippincott, 1991; p. 129.

77. Loddenkemper R, Boutin C. Thoracoscopy: diagnostic and therapeutic indications. Eur Respir J 1993; 6: 1544-1555.

78. Harris RJ, Kavuru MS, Rice TW, Kirby TJ. The diagnostic and therapeutic utility of thoracoscopy: a review. Chest 1995; 108: 828-841.

79. Loddenkemper R. Thoracoscopy - state of the art. Eur Respir J 1998; 11: 213-221.

80. Boutin C, Viallat JR, Cargnino P, Farisse P. Thoracoscopy in malignant pleural effusions. Am Rev Respir Dis 1981; 124: 588-592.

81. Oldenburg FA Jr, Newhouse MT. Thoracoscopy: a safe accurate diagnostic procedure using the rigid thoracoscope and local anesthesia. Chest 1979; 75: 4550.

82. Menzies R, Charbonneau M. Thoracoscopy for the diagnosis of pleural disease. Ann Intern Med 1991; 114: 271-276.

83. Canto A, Blasco E, Casillas M, et al. Thoracoscopy in the diagnosis of pleural effusions. Thorax 1977; 32: 550-554.

84. Boutin C, Viallat JR, Aelony Y. Practical thoracoscopy. Berlin, Springer-Verlag, 1991.

85. Brandt HJ, Loddenkemper R, Mai J. Atlas of diagnostic thoracoscopy. New York, Thieme, 1985.

86. Weissberg D, Kaufmann M, Schwecher I. Pleuroscopy in clinical evaluation and staging of lung cancer. Poumon Coeur 1981; 37: 241-243.

87. Cantó A, Ferrer G, Romagosa V, Moyya J, Bemat R. Lung cancer and pleural effusion: clinical significance and study of pleural metastatic locations. Chest 1985; 87: 649-652.

88. Cantó A, Amau A, Galbis J, et al. The so-called malignant pleural effusion: a new review of direct data obtained with diagnostic pleuroscopy. Arch Bronconeumol 1996; 32: 453-458.

89. Boutin C, Rey F. Thoracoscopy in pleural malignant mesothelioma: a prospective study of 188 consecutive patients. Part 1: Diagnosis. Cancer 1993; 72: 389-393.

90. Boutin C, Rey F, Gouvernet J, Viallat J-R, Astoul P, Ledoray V. Thoracoscopy in pleural malignant mesothelioma: Part 2. Prognosis and staging. Cancer 1993; 72: 394404.

91. International Mesothelioma Interest Group. A proposed new intemational TNM staging system for malignant pleural mesothelioma. Chest 1995; 108: $1122-1128$.

92. Boutin C, Schlesser M, Frenay C, Astoul PH. Malignant pleural mesothelioma. Eur Respir J 1998; 12: 972-981.

93. Boutin C, Dumortier P, Rey F, Viallat JR, DeVuyst P. Black spots concentrate oncogenic asbestosis fibers in the parietal pleura: thoracoscopic and mineralogic study. Am J Respir Crit Care Med 1996; 153: 111119.

94. Levine MN, Young JE, Ryan ED, Newhouse MT. Pleural effusion in breast cancer: thoracoscopy for hommone receptor determination. Cancer 1986; 57: 324-327.

95. Celikoglu F, Teirstein AS, Krellenstein DJ, Strauchen JA. Pleural effusion in non-Hodgkins lymphoma. Chest 1992; 101: 1357-1360.

96. Loddenkemper R. Thoracoscopy: results in noncancerous and idiopathic pleural effusions. Poumon Coeur 1981; 37: 261-264. 
97. Martensson G, Petterson K, Thiringer G. Differentiation between malignant and nonmalignant pleural effusion. Eur J Respir Dis 1985; 7: 326-334.

98. Storey DD, Dines DE, Coles DT. Pleural effusion: a diagnostic dilemma. J Am Med Assoc 1976; 236: 21832186.

99. Hirsch A, Ruffie P, Nebut M, Bignon J, Chretien J. Pleural effusion: laboratory tests in 300 cases. Thorax 1979; 34: 105-112.

100. Lamy P, Canet B, Martinet Y, Lamaze R. Evaluation des moyens diagnostiques dans les epanchements pleuraux. Poumon Coeur 1980; 6: 83-94.

101. Ryan CJ, Rodgers RF, Uni UK, Hepper NG. The outcome of patients with pleural effusion of indetemminate cause at thoracotomy. Mayo Clin Proc 1981; 56: 145-149.

102. Kelly P, Fallouh M, O'Brien A, Clancy L. Fibreoptic bronchoscopy in the management of lone pleural effusion: a negative study. Eur Respir J 1990; 3: 397 398.

103. Feinsilver SH, Barrows AA, Braman SS. Fiberoptic bronchoscopy and pleural effusion of unknown origin. Chest 1986; 90: 516-519.

104. Poe RH, Levy PC, Israel RH, Ortiz CR, Kally MC. Use of fiberoptic bronchoscopy in the diagnosis of bronchogenic carcinoma: a study in patients with idiopathic pleural effusions. Chest 1994; 105: 1663 1667.

105. McKneally MF, Lewis RJ. Statement of the AATS/ STS Joint Committee on thoracoscopic and videoassisted thoracic surgery. Ann Thorac Surg 1992; 54: 1.

106. Light RW, Jenkinson SG, Minh V, George RB. Observations on pleural pressures as fluid is withdrawn during thoracentesis. Am Rev Respir Dis 1980; 121: 799-804

107. Lan RS, Lo SK, Chuang ML, Yang CT, Tsao TCY, Lee $\mathrm{CH}$. Elastance of the pleural space: a predictor for the outcome of pleurodesis in patients with malignant pleural effusion. Ann Intern Med 1997; 16: 768-774.

108. Krell WS, Rodarte JR. Effects of acute pleural effusion on respiratory system mechanics in dogs. J Appl Physiol 1985; 59: 1458-1463.

109. Light RW, Stansbury DW, Brown SE. The relationship between pleural pressures and changes in pulmonary function after therapeutic thoracentesis. Am Rev Respir Dis 1986; 133: 658-661.

110. Perpina M, Benlloch E, Marco V, Abad F, Nauffal D. Effects of thoracentesis on pulmonary gas exchange. Thorax 1983; 38: 747-750.

111. Karetzky MS, Kothari GA, Fouree JA, Khan AU. Effect of thoracentesis on arsenal oxygen tension. Respiration 1978; 36: 96-103.

112. Brandstetter RD, Cohen RP. Hypoxaemia after thoracentesis: a predictable and treatable condition. JAMA 1979; 242: 1060-1061.

113. Brown NE, Zamel N, Abemman A. Changes in pulmonary mechanics and gas exchange following thoracentesis. Chest 1978; 74: 540-542.

114. Sprung CL, Loewenherz JW, Baier H, Hauser JM. Evidence for increased permeability in re-expansion pulmonary oedema. Am J Med 1981; 71: 497-500.

115. Walker-Renard P, Vaughan LM, Sahn SA. Chemical pleurodesis for malignant pleural effusions. Ann Intern Med 1994; 120: 56-64.

116. Hamed H, Fentiman IS, Chaudary MA, Rubens DS. Comparison of intracavitary bleomycin and talc for the control of pleural effusions secondary to carcinoma of the breast. Br J Surg 1989; 76: 12661267.

117. Hartman DL, Gaither JM, Kesler KA, Mylet DM, Brown JW, Mathur PN. Comparison of insufflated talc under thoracoscopic guidance with standard tetracycline and bleomycin pleurodesis for control of malignant pleural effusions. J Thorac Cardiovasc Surg 1993; 105: 743-748.

118. Fentiman IS, Rubens RD, Hayward JL. A comparison of intracavitary talc and tetracycline for the control of pleural effusions secondary to breast cancer. Eur J Cancer Clin Oncol 1986; 22: 10791081.

119. Kennedy L, Rusch VW, Strange C, Ginsberg RJ, Sahn SA. Pleurodesis using talc slurry. Chest 1994; 106: 342-346.

120. Patz EF, McAdams HP, Erasmus JJ, et al. Sclerotherapy for malignant pleural effusions: a prospective randomized trial of bleomycin $v s$ doxycycline with small-bore catheter drainage. Chest 1998; 113: 13051311.

121. Goff BA, Mueller PR, Muntz HG, Rice LW. Small chest-tube drainage followed by bleomycin sclerosis for malignant pleural effusions. Obstet Gynecol 1993; 81: 993-996.

122. Parker LA, Charnock GC, Delany DJ. Small bore catheter drainage and sclerotherapy for malignant pleural effusions. Cancer 1989; 64: 1218-1221.

123. Thompson RL, Yau JC, Donnelly RF, Gowan DJ, Matzinger FR. Pleurodesis with iodized talc for malignant effusions using pigtail catheters. Ann Phannacother 1998; 32: 739-742.

124. Marom EM, Patz EF Jr, Erasmus JJ, McAdams HP, Goodman PC, Hemdon JE. Malignant pleural effusions: treatment with small-borecatheter thoracostomy and talc pleurodesis. Radiology 1999; 210: 277281.

125. Bloom Al, Wilson MW, Kerlan RK Jr, Gordon RL, LaBenge JM. Talc pleurodesis through small-bore percutaneous tube. Cardiovasc Intervent Radio 1999; 24: 433-438.

126. Heffner E, Standerfer RJ, Torstveit J, Unruh L. Clinical efficacy of doxycycline for pleurodesis. Chest 1994; 105: 1743-1747.

127. Pulsiripunya C, Youngchaiyud P, Pushpakom R, Maranetra N, Nana A, Charoenratanakul S. The efficacy of doxycycline as a pleural sclerosing agent in malignant pleural effusion: a prospective study. Respiration 1996; 1: 69-72.

128. Moffett MJ, Ruckdeschel JC. Bleomycin and tetracycline in malignant pleural effusions: a review. Semin Oncol 1992; 19: Suppl. 5, 59-63.

129. Martinez-Moragon E, Aparicio J, Rogado MC, Sanchis J, Sanchis F, Gil-Suay V. Pleurodesis in malignant pleural effusions: a randomized study of tetracycline versus bleomycin. Eur Respir J 1997; 10: 2380-2383.

130. Zimmer PW, Hill M, Casey K, Harvey E, Low DE. Prospective randomized trial of talc slurry $v s$ bleomycin in pleurodesis for symptomatic malignant pleural effusions. Chest 1997; 112: 430-434.

131. Windsor PG, Jackson AC, Windsor KS. Sclerotherapy for malignant pleural effusions: alternatives to tetracycline. South Med J 1994; 87: 709-714.

132. United States Phammacopeia. United States Pharmacopeia XXII, 22nd ed. Rockville, MD, 1990. pp. 13091310. 
133. Kennedy L, Vaughan LM, Steed LL, Sahn SA. Sterilization of talc for pleurodesis: available techniques, efficacy, and cost analysis. Chest 1995; 107 : $1032-1034$.

134. Mattison LME, Sahn SA. More on talc sterilization. Chest 1996; 109: 1667-1668.

135. Todd TRJ, Delarue NC, lives R, Pearson FG, Cooper JD. Talc poudrage for malignant pleural effusion. Chest 1980; 78: 542-543.

136. Kennedy L, Rusch VW, Strange C, Ginsberg RJ, Sahn SA. Pleurodesis using talc slurry. Chest 1994; 106: 342-346.

137. Fentiman IS, Rubens RD, Hayward JL. Control of pleural effusions in patients with breast cancer. Cancer 1983; 52: 737-739.

138. Yin AC, Chan AT, Lee TW, Wan IY, Ho JK. Thoracoscopic talc insufflation versus talc slurry for symptomatic malignant pleural effusion. Ann Thorac Surg 1996; 62: 1655-1658.

139. Weissberg D, BenZeev 1. Talc pleurodesis: experience with 360 patients. J Thorac Cardiovasc Surg 1993; 106: 689-695

140. Viallat JR, Rey F, Astoul P, Boutin C. Thoracoscopic talc poudrage pleurodesis for malignant effusions: a review of 360 cases. Chest 1996; 110: 1387-1393.

141. Kennedy L, Sahn SA. Talc pleurodesis for the treatment of pneumothorax and pleural effusion. Chest 1994; 106: 1215-1222.

142. Kennedy L, Harley RA, Sahn SA, Strange C. Talc slurry pleurodesis: pleural fluid and histologic analysis. Chest 1995; 107: 1707-1712.

143. Lange P, Mortensen J, Groth S. Lung function 22-25 years after treatment of idiopathic spontaneous pneumothorax with talc poudrage or simple drainage. Thorax 1988; 43: 559-561.

144. Knowles JH, Storey CF. Effects of pleural talc poudrage on pulmonary function. $J$ Thorac Surg 1957; 34: 250-256.

145. Paul JS, Beattie EJ, Blades B. Lung function studies in poudrage treatment of recurrent spontaneous pneumothorax. J Thorac Surg 1951; 22: 52-61.

146. Kleinfeld M, Messite J, Kooyman 0, Zaki MH. Mortality among talc miners and millers in New York state. Arch Environ Health 1967; 14: 663-667.

147. Chappell AG, Johnson A, Charles WJ, Seal RME, Berry G, Nicholson D. A survey of the long-term effects of talc and kaolin pleurodesis. Br J Dis Chest 1979; 73: 285-288.

148. Campos JR, Werebe EC, Vargas FS, Jatene FB, Light RW. Respiratory failure due to insufflated talc. Lancet 1997; 349: 251-252.

149. Rehse DH, Aye RW, Florence MG. Respiratory failure following talc pleurodesis. Am J Surg 1999; 177: 437-440.

150. Rinaldo JE, Owens GR, Rogers RM. Adult respiratory distress syndrome following intrapleural instillation of talc. J Thorac Cardiovasc Surg 1983; 85: 523-526.

151. Rodriguez-Panadero F. Talc pleurodesis for treating malignant pleural effusions. Chest 1985; 108: 1178-1179.

152. Sanchez-Ammengol A, Rodriguez-Panadero F. Survival and talc pleurodesis in metastatic pleural carcinoma, revisited: report of 125 cases. Chest 1993; 104: 1482-1485.

153. Sahn SA. Pleural malignancies in pulmonary and critical care medicine. In: Bone RC, Dantzker DR, George RB, Matthay RA, Reynolds HB, eds.
Pulmonary and Critical Care Medicine, 5th ed. St. Louis, MO, CV Mosby, 1997.

154. Lorch DG, Gordon L, Wooten S, Cooper JF, Strange $\mathrm{C}$, Sahn SA. The effect of patient positioning on the distribution of tetracycline in the pleural space during pleurodesis. Chest 1988; 93: 527-529.

155. Dryzer S, Allen ML, Strange C, Sahn SA. A comparison of rotation and non-rotation in tetracycline pleurodesis. Chest 1993; 104: 1763-1766.

156. Petrou M, Kaplan D, Goldstraw P. The management of recurrent malignant pleural effusions: the complementary role of talc pleurodesis and pleuro-pentoneal shunting. Cancer 1995; 75: 801-805.

157. Fry WA, Khandekar JD. Parietal pleurectomy for malignant pleural effusion. Ann Surg Oncol 1993; 160 164 .

158. Al-Katten KM, Kaplan DK, Goldstraw P. The nonfunctioning pleuroperitoneal shunt: revise or replace? Thorac Cardiovasc Surgeon 1994; 42: 310-312.

159. Figlin R, Mendoza E, Piantadosi S, Rusch V. Intrapleural chemotherapy without pleurodesis for malignant pleural effusions LCSG 861. Chest 1994; 106: 363S-366S.

160. Masuno T, Kishimoto S, Ogura T, et al. A comparative trial of LC 9018 plus doxorubicin alone for the treatment of malignant pleural effusion secondary to lung cancer. Cancer 1991; 68: 1495-1500.

161. Ike O, Shimuzu V, Hitomi S, Wada R, Ikada V. Treatment of malignant pleural effusions with doxorubicin hydrochloride-containing poly(-L-lactic acid) microspheres. Chest 1991; 99: 911-915.

162. Rosso R, Rimoldi R, Salvati F, et al. Intrapleural natural beta interferon in the treatment of malignant pleural effusions. Oncology 1988; 45: 253-256.

163. Astoul PH, Viallat JR, Laurent JC, Brandely M, Boutin C. Intrapleural recombinant IL-2 in passive immunotherapy for malignant pleural effusion. Chest 1993; 103: 209-213.

164. Viallat JR, Boutin C, Rey F, Astoul PH, Farisse P, Brandely M. Intrapleural immunotherapy with escalating doses of IL-2 in metastatic pleural effusions. Cancer 1993; 71: 4067-4071.

165. Boutin C, Viallat JR, Van Zandwijk N, et al. Activity of intrapleural recombinant gamma-interferon in malignant mesothelioma. Cancer 1991; 67: 2033-2037.

166. Boutin C, Nussbaum E, Monnet I, et al. Intrapleural treatment with gamma-interferon in early stage malignant pleural mesothelioma. Cancer 1994; 74: 2460 2467.

167. Monti G, Jaurand MC, Monnet I, et al. Intrapleural production of interleukin 6 during mesothelioma and its modulation by gamma-interferon treatment. Cancer 1994; 54: 4419-4423.

168. Hartmann CA, Schutze H. Mesothelioma-like tumours of the pleura: a review of 72 autopsy cases. Cancer Res Clin Oncol 1994; 120: 331-347.

169. Le Roux BT. Bronchial Carcinoma. Edinburgh, E\&S Livingstone, 1968; pp. 127-130.

170. Decker DA, Dines DE, Payne WS, Bernatz PE, Pairolero PC. The significance of cytologically negative pleural effusion in bronchogenic carcinoma. Chest 1978; 74: 640-642.

171. Livingston RB, McCracken JD, Trauth CJ, Chen T. Isolated pleural effusion in small cell lung carcinoma: favorable prognosis. Chest 1982; 81: 208-210.

172. Rodriguez Panadero F. Lung cancer and ipsilateral pleural effusion. Ann Oncol 1995; 6: Suppl. 3, S25-S27. 
173. Weissberg D, Kaufman M, Schwocher I. Pleuroscopy in clinical evaluation and staging of lung cancer. Poumon Cocur 1981; 37: 241-243.

174. Antman KH, Pass Hl, Li FP, Corson J, Delaney T. Benign and malignant mesothelioma. In: Devita VT Jr, Hellman S, Rosenberg SA, eds. Cancer: principles and practice of oncology, 4th ed. Philadelphia, JB Lippincott, 1993; pp. 1489-1508.

175. Antman KH. Natural history and epidemiology of malignant mesothelioma. Chest 1993; 103: 373S-376S.

176. Umsawasdi T, Dhingra HM, Charnsangavej C, Luna MA. A case report of malignant pleural mesothelioma with long-term disease control after chemotherapy. Cancer 1991; 67: 48-54.

177. Johansson L, Linden CJ. Aspects of histopathological subtype as a prognostic factor in 85 pleural mesotheliomas. Chest 1996; 109: 109-114.

178. Fenton FN, Richardson JD. Diagnosis and management of malignant pleural effusions. Am J Surg 1995; 170: 69-74.

179. Ong ST, Vogelzang NJ. Chemotherapy in malignant pleural mesothelioma: a review. J Clin Oncol 1996; 14: $1007-1017$.

180. Rusch VW. Pleurectomy/decortication and adjuvant therapy for malignant mesothelioma. Chest 1993; 103: 382S-384S.

181. Sugarbaker DJ. Extrapleural pneumonectomy, chemotherapy and radiotherapy in the treatment of diffuse malignant pleural mesothelioma. $J$ Thorac Cardiovasc Surg 1991; 102: 10-15.

182. Goey SH, Eggemont AMM, Punt CJA, et al. Intrapleural administration of interleukin 2 in pleural mesothelioma: a phase 1-11 study. Br J Cancer 1995; 72: $1283-1288$.

183. Boutin C, Rey F, Viallat JR. Prevention of malignant seeding after invasive diagnostic procedures in patients with pleural mesothelioma. A randomized trial of local radiotherapy. Chest 1995; 108: 754-758.

184. Raju RN, Kardinal CG. Pleural effusions in breast carcinoma: analysis of 122 cases. Cancer 1981; 48: 2524-2527.

185. Dines DE, Pierre RV, Franzen SJ. The value of cells in the pleural fluid in the differential diagnosis. Mayo Clin Proc 1975; 50: 571-572.

186. Bachmann AL, Macken K. Pleural effusions following supervoltage radiation for breast carcinoma. Radio$\log y$ 1959; 2: 699-709.

187. Lees AW, Hoy W. Management of pleural effusions in breast cancer. Chest 1979; 75: 51-53.

188. Poe RH, Qazi R, Israel RH, Wichs CM, Rubins JM. Survival of patients with pleural involvement by breast carcinoma. Am J Clin Oncol 1983; 6: 523-527.

189. Martin JJ. The Nisbet Symposium: Hodgkin's disease. Radiological aspects of the disease. Australas Radiol 1967; 11: 206-218.

190. Hughes JC, Votaw ML. Pleural effusion in multiple myeloma. Cancer 1979; 44: 1150-1154.

191. Wong FM, Grace WJ, Rottino A. Pleural effusions, ascites, pericardial effusions and edema in Hodgkin's disease. Am J Med Sci 1963; 246: 678-682.

192. Celikoglu F, Teirstein AS, Krellenstein DJ, Strauchen JA. Pleural effusion in non-Hodgkin's lymphoma. Chest 1992; 101: 1357-1360.

193. Whitcomb ME, Schwan Ml, Keller AR, Flannery EP, Blom J. Hodgkin's disease of the lung. Am Rev Respir Dis 1972; 106: 79-85.
194. Jenkins PF, Ward MJ, Davies P, Fletcher J. NonHodgkin's lymphoma, chronic lymphatic leukaemia, and the lung. Br J Dis Chest 1981; 75: 22-30.

195. Xaubet A, Diumenjo MC, Masin A, et al. Characteristics and prognostic value of pleural effusions in non-Hodgkin's lymphomas. Eur J Respir Dis 1985; 6: 135-140.

196. Bruneau R, Rubin P. The management of pleural effusions and chylothorax in lymphoma. Radiology 1965; 85: 1085-1092.

197. Melamed MR. The cytological presentation of malignant lymphomas and related diseases in effusions. Cancer 1963; 16: 413-431.

198. Dewald G, Dines DE, Weiland LH, Gordon H. Usefulness of chromosome examination in the diagnosis of malignant pleural effusions. $N$ Engl $J$ Med 1976; 295: 1494-1500.

199. Whitcomb ME, Schwarz Ml. Pleural effusion complicating intensive mediastinal radiation therapy. Am Rev Respir Dis 1971; 103: 100-107.

200. VanRenterghem D, Hamers J, DeSchryver A, Pauwels R, VanderStraeten M. Chylothorax after mantle field irradiation for Hodgkin's disease. Respiration 1985; 48: 188-189.

201. Mares DC, Mathur PN. Medical thorascopic talc pleurodesis for chylothorax due to lymphoma: a case series. Chest 1998; 114: 731-735.

202. Murphy MC, Newman BM, Rodgers BM. Pleuroperitoneal shunts in the management of persistent chylothorax. Ann Thorac Surg 1989; 48: 195-200.

203. Safa AM, Van Ordstrand HS. Pleural effusion due to multiple myeloma. Chest 1973; 64: 246-248.

204. Rodriquez JN, Pereisa A, Martinez JC, Conde J, Pujol E. Pleural effusion in multiple myeloma. Chest 1991; 105: 622-624.

205. Brambilla C, Brambilla E, Carpentier F, Coulomb M, Stoebuer P, Paramelle B. Pleural immunocytoma with Waldenström's macroglobulinemia. Respiration 1981; 41: 139-144.

206. Sterman DH, Treat J, Litzkey LA, et al. Adenovirusmediated herpes simplex virus thymidine kinase/ ganciclovir gene therapy in patients with localized malignancy: results of a phase I clinical tnal in malignant mesothelioma. Hum Gene Ther 1998; 9: $1083-1092$.

207. Treat J, Kaiser L, Sterman DH, et al. Clinical protocol. Treatment of advanced mesothelioma with the recombinant adenovirus H5.010RSVTK: a phase I trial (BB-IND 6274). Hum Gene Ther 1996; 7: $2047-$ 2057.

208. Shetty S, Kumar A, Johnson A, Idell S. Expression of the urokinase-type plasminogen activator receptor in human malignant mesothelioma cells: role in tumour cell mitogenesis and proteolysis. Am J Physiol Lung Cell Mol Physiol 1995; 12: L972-L982.

209. Idell S, Pueblitz S, Emn S, et al. Regulation of fibrin deposition by malignant mesothelioma. Am J Pathol 1995; 147: 1318-1329.

210. Shetty S, Idell S. A urokinase receptor mRNA binding protein-mRNA interaction regulates receptor expression and function in human pleural mesothelioma cells. Arch Biochem Biophys 1998; 35: 265-279.

211. Shetty S, Idell S. Post-transcriptional regulation of urokinase receptor gene expression in human lung carcinoma and malignant mesothelioma cells in vitro. Mol Cell Biochem 1999; 199: 189-200. 